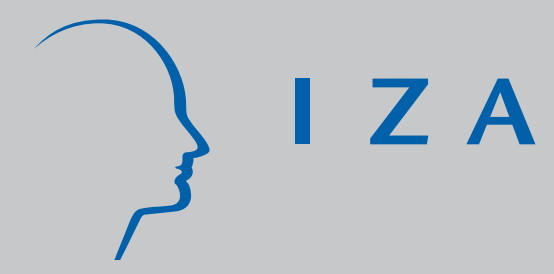

IZADP No. 3422

Wage Effects of Recruitment Methods:

The Case of the Italian Social Service Sector

Michele Mosca

Francesco Pastore

March 2008 


\title{
Wage Effects of Recruitment Methods: The Case of the Italian Social Service Sector
}

\author{
Michele Mosca \\ University of Naples "Federico II" \\ Francesco Pastore \\ University of Naples II \\ and IZA
}

Discussion Paper No. 3422

March 2008

IZA

P.O. Box 7240

53072 Bonn

Germany
Phone: +49-228-3894-0
Fax: +49-228-3894-180
E-mail: iza@iza.org

\begin{abstract}
Any opinions expressed here are those of the author(s) and not those of IZA. Research published in this series may include views on policy, but the institute itself takes no institutional policy positions.

The Institute for the Study of Labor (IZA) in Bonn is a local and virtual international research center and a place of communication between science, politics and business. IZA is an independent nonprofit organization supported by Deutsche Post World Net. The center is associated with the University of Bonn and offers a stimulating research environment through its international network, workshops and conferences, data service, project support, research visits and doctoral program. IZA engages in (i) original and internationally competitive research in all fields of labor economics, (ii) development of policy concepts, and (iii) dissemination of research results and concepts to the interested public.
\end{abstract}

IZA Discussion Papers often represent preliminary work and are circulated to encourage discussion. Citation of such a paper should account for its provisional character. A revised version may be available directly from the author. 


\section{ABSTRACT \\ Wage Effects of Recruitment Methods: The Case of the Italian Social Service Sector ${ }^{*}$}

This paper uses a unique data set containing detailed micro-information on organisations, managers, workers and volunteers belonging to public, private forprofit and private nonprofit institutions delivering social services in Italy. The analysis aims to estimate the determinants of wages across organisations at a sector level focusing on the role of hiring and job search methods, including informal networks. We find that, independent of the organisation type, being hired through public competitions brings with it a substantial wage premium (ranging from 7 to 32\%). Informal networks bring with them a wage penalty $(-6.5 \%)$ in the state sector, where formal hiring methods are common, and a wage premium (6.3\%) in social cooperatives and religious institutions, where formal hiring methods are not common. Interestingly, the differences in hiring and in job search methods between state and private organisations explain from $50 \%$ to $100 \%$ of the conditional wage differentials across organisation types. Our interpretation of these findings is that nonprofit organisations prefer informal recruitment methods not for nepotistic reasons, but to better select the most motivated workers, those who share the nonprofit mission. This paper adds to the previous literature by suggesting that in addition to lower than average monetary compensations, informal recruitment methods are part of the process of self-selection of motivated workers in nonprofit organisations.

JEL Classification: I11, J31 J41, L31, L33, L84

Keywords: informal networks, earnings functions, social services, nonprofit organisations, Italy

Corresponding author:

Francesco Pastore

Seconda Università di Napoli

Palazzo Melzi

Piazza Mazzocchi

80135 Santa Maria Capua Vetere (CE)

Italy

E-mail: fpastore@unina.it

\footnotetext{
* A previous version of this paper has been presented at the First Annual Scientific Meeting on Social Enterprise, University of Naples "Federico II", 11-12 May 2007. We thank all seminar participants for useful suggestions. However, the responsibility of any errors remains only ours.
} 


\section{Introduction}

During the last decade there has been an increasing interest in investigating the causes of the expansion of private organisations in the social service sector in Italy. Several scholars, policy makers and opinion leaders have raised a number of criticisms on the nature of the sector's performance. Without entering fully the debate, it is worth noting that several observers have claimed that private, especially nonprofit organisations have played a marginal role in terms of employment growth and, furthermore, that they have tended to employ unskilled workers to supply services of low quality. Hiring their personnel through informal recruitment channels would be essential to the survival strategy of nonprofits since they belong to and depend financially on political lobbies. Because of the large use of recommendations in the recruitment process, skill mismatch would be frequent $^{1}$ and it is usually considered one of the main explanations of the low returns to education that these organisations would pay (see, among others, Carinci, 2001) $)^{2}$.

This paper attempts to address these criticisms in two ways. First, it studies the returns to education in the social service sector to test whether workers are paid less than the country's average. The econometric analysis is based on the ISSAN data and includes information on three juridical forms of organisation: state, private forprofit and private nonprofit organisations. This allows us asking and answering the questions whether nonprofit organisations employ lower productivity workers and pay them less than other types of organisations within the sector. In fact, previous contributions have already studied the determinants of the nonprofit wage gap (see, for instance, Preston, 1989; Leete, 2000; and 2001; Ruhm and Borkoski, 2000; Pestana Barros, 2006; Mosca, Musella and Pastore, 2007), though leaving aside the issue of the possible differences in returns to human capital across organisations' types. This paper finds clear evidence that the

1 In fact, the use of informal contacts, such us the help of family and friends or other forms of recommendations, is a common search and recruitment strategy in the U.S., as Corcoran, Datcher and Duncan (1980), Holzer (1988) and Ioannides and Datcher Loury (2004), among others, note, but also in the UK (Gregg and Wadsworth, 1992), in the European Union (Pellizzari, 2004) and in Italy (Pistaferri, 1999; Meliciani and Radicchia, 2005).

${ }^{2}$ As discussed at more length later on in this paper, if organisations are in a way "forced" to hire workers with qualification types that they do not really need, they will tend to pay for such qualifications lower wages than those other organisations more in need would be available to pay. 
nonprofit wage gap is not due to differences in human capital characteristics and that returns to human capital are in nonprofit organisations not lower than in other competing organisations. A sizeable conditional wage gap across organisations persists after controlling for all observed differences.

Second, the paper aims to assess the relative impact of different recruitment channels, and of informal networks in particular, on wage structures across organisations in the social service sector. While the impact of recruitment methods on wages has been addressed in several previous contributions, none of them focuses on social services. In addition, comparison of outcomes across organisation types within the same sector is another novelty of this as compared to previous studies that generally focus on differences across sectors or, more recently, across countries. It allows us considering constant institutional differences, but at the cost of running the risk that recruitment channels might possibly catch unobserved sector specific factors, such as a low level of productivity of jobs and workers.

From a theoretical point of view, since the work of Montgomery (1991) and Mortensen and Vishwanath (1994), “informal channels”, namely the help of friends and relatives in finding a job, have been taken to represent the way in which employers can overcome the asymmetric information problem. Recommendations from friends and relatives would be a signal of the productivity level of workers and their ability to fulfil the available vacancies. Based on this theoretical analysis, Montgomery (1991, p. 1414) concludes that "workers who are well connected (possessing social ties to those in high-paying jobs) might fare better than those who are poorly connected". In other words, one should expect that workers hired through (strong) informal networks should earn a wage premium as compared to their poorly connected colleagues who have found their job through other channels.

In contrast with these early theoretical predictions, with few exceptions relative mainly to Anglo-Saxon countries and high skill labour markets (Simon and Warner, 1992; Kugler, 2003; Goos and Salomons, 2007), the available empirical evidence concurs to reach the conclusion that the wage effect of informal channels is neither positive nor constant across sectors and countries 
(see, among others, Pistaferri, 1999; Pellizzari, 2004; Bentolila, Michelacci and Suarez, 2004; Meliciani and Radicchia, 2005; Antoninis, 2006; Delattre and Sabatier, 2007; Weber and Mahringer, 2007; Pastore, 2008).

These authors have sought explanations of contrasts between theory and evidence, which are detailed in Section 1. In short, the main explanation is that informal networks are more common among low qualified workers, whose labour market is less affected by asymmetric information problems. In these markets, informal networks represent a negative, not a positive signal for employers. This does not need to mean, though, that referrals are only due to unobserved job characteristics that might cause compensating wage differentials as one might argue based on a reverse causality hypothesis (Pistaferri, 1999; Delattre and Sabatier, 2007).

Pellizzari (2004) brings to the fore a further explanation of the variance across countries of the wage effect of referrals. A negative wage effect would be typical of labour markets where formal recruitment methods are more common, as it is the case especially of the public sector in most European countries, including Italy. In this case, informal channels are generally considered a cheap selection device. In fact, it is common to consider informal channels a way for lobbies to affect the employer's hiring decision, like in Goldsberg's (1982) model of nepotistic firms, rather than an instrument to gather information on job applicants. This paper is one of the few available ones to compare informal and formal channels of recruitment.

As noted at the outset of this Introduction, the case of social services is interesting in as much as informal channels of recruitment are, according to several opponents of nonprofit organisations (Carinci, 2001), more common than in other sectors. In fact, this paper provides evidence that informal networks are more common in nonprofit than in public organisations, but are as common as in profit-seeking organisations. The difference between state and private organisations is to be found first in the legal obligation for the former to hire through formal recruitment methods, especially public competitions. Independent of the organisation type, being hired through public competitions brings with it a substantial wage premium (ranging from 7 to 32\%). Controlling for methods of 
selection of personnel (public competition, some form of selection, no selection, do not answer), informal networks bear a wage penalty (with a coefficient of $0.065)$ in the state sector, and a wage premium $(+0.063)$ in social cooperatives and religious institutions. Informal networks are statistically insignificant determinants of earnings for workers in forprofit and in lay nonprofit organisations. This confirms the hypothesis that the information content of informal networks is higher when formal recruitment methods are not common. Interestingly, the differences in hiring and in job search methods between state and private organisations explain $50 \%$ through $100 \%$ of the conditional wage differentials across organisation types. Our interpretation of these findings is that nonprofit organisations prefer informal recruitment methods to better select the most motivated workers, namely those workers who share the nonprofit mission. This paper adds to the previous literature by suggesting that in addition to lower than average monetary compensations, informal recruitment methods are part of the process of self-selection of motivated workers in nonprofit organisations.

The paper is organised as follows. Section 1 reviews the theoretical and empirical literature on wage effects of informal contacts. Section 2 presents the methodology used to estimate the determinants of wages and the impact of hiring and job search methods. Section 3 illustrates the main features of the ISSAN databank. The following two Sections report the results that Section 6 discusses. Some concluding remarks follow.

\section{The theoretical and empirical evidence on the informal contacts}

Theoretical reasoning predicts that informal networks, here intended as the help of friends and relatives ${ }^{3}$ in finding a job, exert two main effects: first of all, they increase the probability of being hired and, second, they produce a positive effect on earnings (Montgomery, 1991; Mortensen and Vishwanath, 1994) ${ }^{4}$. First, informal contacts are supposed to be able to signal the right worker for the right

\footnotetext{
${ }^{3}$ In fact, the early literature on informal networks has focused on professional ("old boys”), rather than family networks (see, for instance, Simon and Warner, 1992). Some recent empirical literature distinguishes the relative impact of these two types of networks, finding a positive wage effect in the former case and a negative one in the latter case (Sylos Labini, 2004; Antoninis, 2006; Datcher Loury, 2006).

${ }^{4}$ See Ioannides and Datcher Loury (2004) for a more comprehensive literature review.
} 
job therefore increasing her probability of being employed. Second, by reducing the ex ante information asymmetry between employer and employee, job referral mechanisms allow selecting the more productive workforce and therefore paying them higher wages.

Another explanation of the use of informal contacts is connected to cost benefit considerations for employers and job seekers. On the one hand, employers could find it convenient to use informal recruitment methods as a screening device to reduce the higher costs that are supposedly associated with other more formal selection procedures. On the other hand, job search theory predicts that also job seekers evaluate marginal benefits and marginal costs from any given search alternative. They would prefer to use informal contacts because these last bring higher marginal benefits and are less expensive in comparison to formal selection methods. The benefits mirror the already mentioned expected employment and earnings gains (Datcher Lury, 2006, p. 2). Many factors can affect the relative cost of job search. First, participation to a public competition with other candidates implies to bear not only the cost to achieve a sufficient level of human capital endowment, but also of preparing for the competition. In addition, a long period of unemployment could reduce the reservation wage and, hence, increase the use of family and friends recommendations to reduce the cost of job search (Obserg 1993, Thomas, 1997). Additionally, being a member of social networks could reduce the cost and therefore increase the use of informal contacts.

A third line of reasoning to explain positive effects of informal networks on job finding and wages is based on Goldberg's (1982) hypothesis of nepotistic firms. He obtains a positive impact of informal networks for referred individuals as a result of a theoretical model in which nepotistic firms maximise utility rather than profits. They would prefer to use referrals or nepotistic practices to distribute part of the profit in terms of utility or non-monetary compensations to their personnel, although this would cause lower profits. The co-existence of nepotistic firms with discrimination neutral firms would be guaranteed by the tendency of the former to distribute their profits to stakeholders, including employees within the firm. 
The empirical evidence reported in Table 1 is unanimous in confirming the expected impact of informal networks on the probability of job finding, but is at variance with theoretical predictions when assessing their impact on earnings. A large literature finds evidence that informal contacts reduce the information asymmetry between employer and employee, reduce the mismatch between labour demand and supply and hence allow referred workers obtaining the right job more easily. Empirical studies show that informal networks increase the number of offers per contact, which explains also why 30 through $60 \%$ of all employed workers found their job through friends and relatives (Holzer 1987b; and 1988; Roper, 1988; Jones, 1989; Blau and Robins, 1990; Obsberg, 1993; Datcher Lury, 2006; Goos and Salomon, 2007) ${ }^{5}$.

Nonetheless, employees hired through informal contacts not only declare a lower level of job satisfaction (Addison and Portugal, 2002), but also lower wages as compared to those hired through other entry channels. With few exceptions mainly related to the Anglo-Saxon case (Simon and Warner, 1992; Marmaros and Sacerdote, 2002; Kugler, 2003, for the USA; and Goos and Salomons, 2007, for the UK), previous research has found a negative wage effect of informal networks (see Pellizzari, 2004; and Bentolila, Michelazzi and Suarez, 2004, for a number of EU countries; Datcher Loury, 2006, for the USA; Antoninis, 2006 for Egypt; Weber and Mahringer, 2007, for Austria; Delattre and Sabatier, 2007, for France; Pastore, 2008, for Mongolia). Margolis and Simonnet (2003) find a positive wage effect for France, but focus on high skill jobs. Collier and Garg (1999) find evidence of the existence of a wage premium for members of a kin group in state sector jobs in Ghana.

A wage penalty is invariantly found in all studies relative to Italy. Using the 1991 and 1993 waves of the SHIW (Survey of Household Income and Wealth) databank collected by the Bank of Italy, Pistaferri (1999) finds a negative coefficient $(-0.046)$ of informal networks as compared to any other job search method. The coefficient shrinks to -0.031 when controlling for low skill sectors and occupations. Sylos Labini (2004) confirms this result for 1998 using the same

\footnotetext{
${ }^{5}$ For the sake of brevity, this discussion focuses on wage effects, which are more relevant for the rest of the paper. See Ioannides and Datcher Loury (2004), and the first heading of Table 1, for a detailed survey of the literature on employment effects of informal networks.
} 
data. He finds a wage penalty of -0.025 , when there is no control for the type of referral. The wage penalty associated with family and friends' referrals becomes 0.047 when controlling for the presence of a network of colleagues, which yields a wage premium of 0.025 . Meliciani and Radicchia (2005) use data collected by ISFOL (Institute for the Development of the Vocational Training of Workers) in 2003. They find a wage penalty of -0.037 for workers hired using informal networks as compared to those hired through public competitions, direct applications, direct experience on the job and referrals through school.

\section{[Table 1 about here]}

These authors have sought theoretical explanations of contrasts between theory and evidence. The most common explanation of negative wage effects is that informal networks are more common among low qualified workers, whose labour market is less affected by the asymmetric information problems. In these markets, informal networks represent a negative, not a positive signal for employers. This is especially the case of developing countries, where average education attainment is low and fails to be a good signal of the quality level of workers, as Antoninis (2006) notes. Simon and Warner (1992), Marmaros and Sacerdote (2002), Kugler (2003) and Margolis and Simonnet (2003) find a wage premium focusing on high skill jobs, where informal networks should play a more important role.

This does not need to mean, though, that referrals are only a sign of low (Pistaferri, 1999; Pellizzari, 2004; Antoninis, 2006) or high productivity as one might argue based on a reverse causality hypothesis. In other words, as, among others, Ioannides and Datcher Loury (2004) and Datcher Loury (2006) argue, the wage effect of referrals might be spurious, mirroring the impact of unobserved job or individual heterogeneity, rather than of referrals themselves. Pistaferri (1999) does find that IV estimates using father's education and occupation as instruments increase the absolute value of the coefficient of informal networks, concluding that OLS underestimates the real effect of informal networks. This would suggest, hence, that the wage penalty of referrals partly depends on the impact of skills. Nonetheless, the impact is limited in size. Weber and Mahringer (2007) reach a similar conclusion using an ad hoc approach to the search of suitable instruments 
to exogenise informal networks. Their coefficient moves from around zero to 0.18, but remains statistically insignificant. Delattre and Sabatier (2007) find no effect at all of informal networks on wages using both OLS and IV estimates. However, they find a statistical significant wage penalty of about $7 \%$ when implementing a switching regression model. They conclude that their findings can be interpreted as lending support to the hypothesis that network's users can have unobserved attributes, negatively correlated with wages.

Pellizzari (2004) uses a different strategy from IV estimates to test for an exogenous effect of informal networks concluding that informal networks bear a negative impact on wages only for short tenured workers as one would expect if referrals themselves and not some kind of mismatch between workers and jobs was the cause of lower wages. If referrals are just a sign of low productivity jobs, their negative impact on wages should persist also after long job tenure. In fact, it is a common finding of previous studies that the wage effect of informal networks tends to disappear with time passing (see, for instance, Simon and Warner, 1992; and, for a survey, Ioannides and Datcher Loury, 2004, p. 1059).

Pellizzari (2004) brings to the fore a further explanation of the negative impact of referrals on wages, which is of particular interest for this study. Wage penalties would be typical of countries where formal recruitment methods are more common. The more firms are available to spend in formal recruitment methods, the greater is also the amount of information that they can draw directly from job applicants and the less worthy is, then, the information attained through informal channels. In the USA, where formal channels are less common, informal networks are more influential, whatever the qualification of a job vacancy is. Informal networks become an effective way to reduce the cost of gathering information on the quality of job applicants directly from them. Consequently, at least for high qualified workers, informal networks might cause higher, not lower wages. Conversely, where formal channels are more common, as it is especially the case of public sector jobs in most European countries, including Italy, informal channels are generally considered a cheap way to fill in job vacancies. In fact, it is common to consider informal channels a way for lobbies to affect the employer's hiring decision, rather than an instrument to gather information on job 
applicants. With the exceptions of Sylos Labini (2004), Meliciani and Radicchia (2005) and Margolis and Simonnet $(2007)^{6}$, this is one of the few papers to compare formal and informal recruitment channels.

What are the expectations about the wage effects of informal networks in the social service sector? And what are the possible differences across organisation types? Two different answers have been provided in the literature. As already noted, some authors (see, among others, Carinci, 2001) argue that nonprofit organisations would tend to use informal networks more often than other types of organisations as a tool to achieve political and financial support, like in Goldberg's (1982) model. Based on this prediction, informal search methods should be associated with lower wages. Implicit in this first interpretation is the assumption that informal are less able than formal recruitment methods in solving the ex ante information asymmetries across organisations.

This paper proposes a different interpretation, which is based on previous research on nonprofit organisations. Some authors (see, for instance, Preston, 1989) claim that workers in nonprofit organisations would incorporate in their subjective utility function also the satisfaction of social needs and would be available to be paid less to reach their social aims. On a similar vein, Mosca, Musella and Pastore (2007) suggest a theoretical framework to explain the nonprofit wage gap where, like in Akerlof (1984), the worker's effort correlates not only with wages, but also with non-monetary compensations. These take the form of relational goods and services by-produced in the delivery of particular services. As formalized in Handy and Katz (1988), by paying lower pecuniary compensations (but higher non-pecuniary compensations), the nonprofit sector is able to attract similarly skilled, but intrinsically more motivated workers, able to provide, in principle, a higher level of effort than their counterparts in the forprofit sector.

This paper extends previous research by introducing in the empirical analysis hiring and job search methods to test whether: a) such methods differ across organizations; b) and whether such differences may contribute to explain

\footnotetext{
${ }^{6}$ Pellizzari (2004) cannot directly compare hiring and job search channels, because the data he uses (the European Community Household Panel) does not allow identifying workers that obtained their job by winning public competitions.
} 
organizational wage differentials. The underlying hypothesis is that search methods cannot be ranked according to their different ability to obtain the same set of information as hypothesised in the previous literature on informal networks, but that they satisfy different informational needs. More specifically, the information content of informal contacts might be different from that of formal selection methods: such individual characteristics as work ethic and motivation might not be easy to achieve through answers to tests or direct interviews. Consequently, different organisation types might choose different recruitment strategies. As also Devaro (2005) notes, nonprofit organisations might prefer informal methods which are aimed not only at assessing the productivity level in candidates, which can be better assessed with more formal methods, but also their degree of motivation and the sharing of the ideological aims and the mission of nonprofit organizations.

\section{Aims and methodology}

The standard Mincerian approach allows estimating returns to education across organisations and wage effects of recruitment methods. The equilibrium condition of the present value of the (expected) income in a certain year is equal to the cost of the investment. It can be proven that the internal rate of return to schooling can be approximated by the difference in the logarithm of wages between leaving education at a given year and leaving it in the previous year. The augmented or "extended" version of the earnings equation is:

(1) $\ln w_{i}=\alpha_{i}+r s_{i}+D x_{i}+G x_{i}^{2}+u_{i}$

where $w_{i}$ is the net hourly earnings for an individual $i, s_{i}$ represents a measure of his/her schooling, $x_{i}$ is a measure of work experience and $u_{i}$ is the usual disturbance term, assumed independent of $x_{i}$, that represents other elements the model does not directly capture. Squared work experience is used to capture the concavity of the earnings profile. The term $r$ reflects the private financial return to schooling as well as being the proportionate effect on wages of an increment to $s$. Expression (1) represents a log-linear transformation of an exponential function and can be estimated by OLS. The coefficients have a semi-elasticity 
interpretation: they measure the ceteris paribus percentage change in the dependent variable for any unit change in any independent variable ${ }^{7}$.

The wage effect of informal networks can be estimates augmenting equation (1):

(2) $\ln w_{i}=\eta I N_{i}+r s_{i}+D x_{i}+G x_{i}^{2}+u_{i}$

where $I N$ is a dummy equal to 1 if individual $i$ has used informal networks to find her/his current job. The coefficient of $I N$ is the estimated value of the wage effect of informal networks. The ISSAN dataset allows controlling also for different recruitment methods (RM), as detailed in the next section. To take them into account, equation (1) is then further augmented:

(3) $\ln w_{i}=\eta I N_{i}+\psi R M_{i}+r s_{i}+D x_{i}+G x_{i}^{2}+u_{i}$.

As Pellizzari (2004) notes, the existence of wage differentials between jobs found through formal and informal contacts can be explained in two different ways. First, jobs obtained through informal networks could be associated with unobserved job specific characteristics: in this case, wage penalties (or wage premiums) would compensate for non monetary benefits related to the job, such as job security and stability, responsibility or effort. In case of nonprofit organisations operating in the provision of social services, lower wages might be the compensation for better relations among colleagues, sharing the organisation's aims and so on. If this is the case wages reflect compensating differentials for some specific job characteristics. Alternatively, wage differentials found through formal and informal contacts and/or methods of search could depend on mismatch of the right worker to the right job. Empirically, if wage differences depend on compensating differentials then they should not vanish with job tenure. On the contrary, if they are due to mismatch between jobs and workers they should disappear once workers move to a better job. To test these two alternative hypotheses, equation (4) modifies equation (3) by introducing two interactions of

\footnotetext{
${ }^{7}$ When the regressor is a continuous variable, such as years of education, the elasticity at the mean of the covariates, namely the percentage change in the regressor, can be calculated multiplying the coefficient by the mean of the regressor: $\beta X$. When treating independent dummy variables, such as being a woman, the semi-elasticity interpretation is flawed and Halvorsen and Palmquist (1980) propose the following formula: $(\mathrm{e} \beta-1)^{*} 100$. It measures the percentage change in the median wage, which is less influenced by outliers. It is possible to interpret the estimated coefficient of dummy variables directly as semi-elasticity if the estimated coefficient is close to zero.
} 
the dummy for informal networks and recruitment methods with one for low and one for high job tenure:

$$
\begin{aligned}
& \ln w_{i}=[\eta I N * \text { LowTenure }+\eta I N * \text { HigTenure }]+ \\
& (4)+[\psi R M * \text { LowTenure }+\psi R M * \text { HigTenure }]+ \\
& +r s_{i}+D x_{i}+G x_{i}^{2}+u_{i}
\end{aligned}
$$

If the coefficients of the two interactions are statistically different from each other, then, one can assume that informal networks are an independent factor of wages; viceversa, if we cannot reject the hypothesis $\mathrm{H}_{0}$, then, we can conclude that informal networks are a signal of skill.

A job tenure of more than two years is considered to be high in this paper, since two years are necessary for workers and firms to understand whether informal networks have led to some form of worker-to-job mismatch. In addition, workers need a sufficient time to implement successfully their "job shopping" activity and firms to adjust wages to the real skill level of their workers. The high unemployment rate typical of social services in Italy makes it more difficult to search for better alternative employment opportunities.

\section{Data and variables}

The empirical analysis is based on the Survey on Employment in the Social Care and Educational Services that ISSAN ${ }^{8}$ has conducted in the first semester of 1998 on Italian state, forprofit and nonprofit organisations operating in the supply of such social services as Assistance and guardianship, Nursing/Rehabilitation, Educational, Cultural, Recreational, School and school-to-work guidance, Jobsearch assistance and others (see Borzaga, 2000, for further details on the data bank).

The survey was carried out in fifteen provinces ${ }^{9}$, mainly concentrated in the Northern regions, where nonprofit organisations are more numerous. 724 voluntary workers, 2066 (out of 9226) paid workers, 228 organisations, divided in

\footnotetext{
${ }^{8}$ Istituto di Studi sullo Sviluppo delle Aziende Nonprofit (En. Tr.: Institute of Studies on the development of Nonprofit Organisations).

${ }^{9}$ From North to South: Trento, Gorizia, Pordenone, Trieste, Udine, Venezia, Cuneo, Torino, Brescia, Firenze, Napoli, Salerno, Catanzaro, Reggio Calabria and Messina.
} 
268 units, and 266 managers filled in the questionnaires. About $61.7 \%$ of paid workers in the sample are employed in the nonprofit organisations, of which $33 \%$ are in the lay nonprofits, $29.3 \%$ are in the public organisations and $9.0 \%$ in the forprofit organisations. The data set provides detailed information on education attainment, work experience, wages, different levels of work satisfaction, linked to wages, job, organisation and relations among colleagues, as well as on hiring and job search methods.

The natural logarithm of net hourly wages $\left(\operatorname{Ln}\left(w_{h}\right)\right)$, as obtained by dividing the declared average monthly wage after $\operatorname{tax}^{10}$ by contractual hours, is the dependent variable in estimates of earnings equations ${ }^{11}$. The independent variables can be grouped into individual characteristics, environmental variables, as well as, at a later stage, job search and hiring methods.

Individual characteristics include a gender dummy variable for men and two dummy variables for civil status (singles and divorced/widowed). Various forms of human capital endowment are considered. Schooling is measured in years of completed education, according to the Italian education system: primary school (5 years), low secondary school (8), professional qualification (11), high secondary school (13), bachelor degree (16) and the traditional University degree (18) ${ }^{12}$. In most estimates, education is measured in terms of educational qualifications above the compulsory level, rather than in terms of years of schooling, to test for non-linearity in returns to educational attainment levels (Psacharopoulos, 1994).

Moreover, following a standard procedure, potential work experience is computed as age minus years of schooling minus the six years, when schooling

\footnotetext{
${ }^{10}$ Interviewees are asked: "Could you please indicate the average net monthly wage you received in the last months (exclusive of extra-work pay, arrays and so on)?”

${ }^{11}$ A small number of sampled individuals (9.5\%) do not declare either their monthly wage (6.8\%) or their contractual hours (4.1\%). As an experiment, missing observations have been replaced by mean values of the variable distinguished by organisation type. The pre- and post transformation average wages differ only by less than $1 \%$. However, results based on estimates of the same equations on the original and on the transformed dependent variable show that the results are not robust to the change in the dependent variable. As a consequence, the transformed wages are discarded.

12 The statutory years for the traditional university degree vary from 4 (in general) to 5 years (for Engineering and Medical science). Nonetheless, the average actual years of attendance necessary to gain a university degree is over 7-8 years according to the type of degree. This might suggest that the estimated returns to a year of education overestimate the true returns in the Italian. A reform implemented in the second half of the 1990s has allowed a new type of University degree that is possible to achieve in three years. This second type of degree is called Bachelor degree.
} 
starts. The long time of job search necessary to individuals to find a job in Italy would suggest that the variable used overestimate the return to a year of work experience. The hypothesis of non-linearity of returns to work experience is tested including a quadratic term. Job specific work experience is caught by the declared tenure as measured in years since the respondent started to work in the current job.

A variable measuring the age of the organisation is used to test whether old organisations, considered more stable, pay higher wages. In fact, this variable can be considered also a proxy for firms' size, which is unobserved in the data set, but is usually found to significantly affect wage levels.

Dummies for groups of regions are included in the estimates. One would expect that wages paid by organisations operating in less developed Southern to be lower than in Centre-Northern regions considering the lower cost of living of the former ${ }^{13}$.

The organisations are divided into state (State), for-profit (FPOs) and nonprofit organisations (NPOs). The latter include social cooperatives, religious and lay institutions. Social cooperatives were legally recognised in 1991 (Law 381) and can be of two types: Type A provide health, social or educational services, while Type B integrate disadvantaged people into the labour market and at least $30 \%$ of their members must be from the disadvantaged target groups. The categories of disadvantage the latter target may include physical and mental disability, drug and alcohol addiction, developmental disorders and problems with the law. They do not include other factors of disadvantage such as race, sexual orientation or abuse. Lay and religious organisations differ for the aims they pursue: religious institutions tend to pursue aims similar to the social cooperatives. These differences within the NPOs could clearly affect also the mechanism of wage determination. Therefore, the analysis groups together social cooperatives and religious nonprofits (NPO1) to distinguish them from lay nonprofits (NPO2).

\footnotetext{
${ }^{13}$ The authors experimented with control variables to catch the effect of the higher cost of living in big cities, as compared to small provinces. However, these variables turned out to be statistically insignificant and were excluded from the estimates.
} 
Environmental factors include sector, occupation, professional qualification and type of contract. The questionnaire distinguishes eight sectors, which have been aggregated into four to have larger cell sizes: Nursing Services, Recreational Services, Training and School-to-work Services, Assistance at Home. All the other services are used as baseline. These fixed effects allow us controlling also for firm's size and skill level differences across sub-sectors.

The occupations considered in the questionnaire are ten, of which only six had a sufficient number of observations to be included in the estimate: Assistant at Home, Social Assistance Operator ${ }^{14}$, Generic and Professional Nurse, Social Therapist and Educator / Teacher. The rest (9.1\%) is pooled together with the large group of those not answering the question (41.7\%), to be the baseline.

Dummies for part-time and temporary work are included to test for possible differences in wage penalties across organisations. This would be especially the case of NPOs according to anecdotal evidence. Other control variables include having a professional title to work in NPOs and holding a particular type of contract. To catch the possible effect of union membership, a dummy is included for those who always go on strike when requested by the unions.

A positive feature of the ISSAN data is that it allows controlling for hiring and job search methods. Regarding hiring methods, the questionnaire asks respondents whether their job was obtained through public competitions or direct hiring. In the latter case, respondents are asked whether they were hired after some form of selection or without any selection. A specific dummy is included for those who do not declare their method of selection. Information on hiring channels is important for two reasons. First, it allows distinguishing three different levels of selection. Second, it allows assessing the joint effect of hiring and jobs search methods and therefore testing the hypothesis that the wage effect of informal networks is greater if hiring methods are less formal (Pellizzari, 2004). This is possible also because different organisation types adopt different hiring methods.

\footnotetext{
${ }^{14}$ Social Assistance Operator is the same as Social Assistant, but is a type of occupation that is formally defined by the law.
} 
In addition, the questionnaire reports information on the following job search methods that workers have adopted to find their current job: a) having a previous relationship of professional collaboration with the organisation, b) having an affiliation to an association or group (religious or not) to which the organisation is connected; c) having previously been on duty for the voluntary service within the organisation; c) having been previously a customer (or customer' relative) of the services delivered by the organisation; d) having been previously signalled by friends or relatives; e) having a previous direct knowledge of the organisation because it operates in the residential area of the interviewee; f) having acted as a volunteer within the organisation; g) having answered to a job advertisement published in specialised newspapers; h) having contacted the public or a private employment office; i) having used other methods. Only one option is given to respondents. Option i) is chosen as baseline. Unfortunately, the ISSAN data does not allow us distinguishing professional networks from networks of family and friend.

\section{Wage differentials by organisation}

As reported in Table 2, on average governmental organisations pay higher monthly wages than private firms. The unconditional wage gap of state over private profit-seeking firms amounts to $9.6 \%$ when considering all workers and to $12.4 \%$ when considering only full-time workers. Interestingly, profit-seeking firms pay their part-time employees higher (monthly) wages than both governmental (12.2\%) and nonprofit (16.6\%) organisations. Especially social cooperatives (25.9\%) and other religious nonprofit organisations (18.6\%) pay lower (monthly) wages to part-time workers than those of their profit-seeking pairs. This explains why the state/private wage gap is higher for full-time workers than for all workers ${ }^{15}$.

\section{[Table 2 about here]}

\footnotetext{
15 This data has to be read with caution. In fact, forprofit organisations pay higher monthly wages to part-time workers also because these work a greater number of hours as compared to their pairs in other sectors. When we look at hourly wages of part-time workers, it appears that the State and NPO1s pay more than the NPO2s and FPOs.
} 
The comparable figures of the wage gap of state over nonprofits are $16.2 \%$ for all workers and $13.1 \%$ for the full-time, respectively. However, there are strong wage differences between NPO1s and NPO2s. The state sector pays higher wages than NPO1s by 7\% for all workers and 5.5\% for the full-time. As already noted, NPO2 includes social cooperatives and other religious nonprofit organisations. Social cooperatives pay $22.7 \%$ less than the state to all workers and $16.8 \%$ to full-time workers. Other religious nonprofit pay $17.8 \%$ less than the state to all workers and $18.2 \%$ less to full-time workers.

The comparison between forprofit and nonprofit organisations highlights a positive wage premium (6\%) in favour of the former when all workers are included into the analysis. This result is much lower than the $18 \%$ reported in Preston (1989) for the USA for the entire universe of nonprofit organisations and not only those operating in the social service sector. The nonprofit/forprofit wage gap almost vanishes when considering full-time workers (0.6\%): in fact, most of the forprofit/nonprofit wage gap depends on the higher remuneration that the former type of organisations pays to part-time workers. Similar to the USA (see Leete, 2001), also in the Italian case the nonprofit/forprofit wage gap in hourly wages is not statistically significant for all workers. This essentially depends on the share of part-time workers in nonprofit organisations (25.3\%), which is almost double that in forprofit firms (14.2\%) and in governmental institutions (14\%). Leete (2001, tab. 2) also reports that the share of part-time labour is double in the nonprofit (16.5\%) as compared to the forprofit (9.8\%) sector in the USA.

Notice that the unconditional nonprofit/forprofit monthly wage gap goes up to $10.6 \%$ when the analysis excludes the lay organisations (NPO1). In fact, these last pay higher monthly wages (2.4\%) than their forprofit counterparts and than the rest of nonprofits (13.3\%; NPO2).

To sum up, the previous analysis shows that public organisations remunerate their workforce with higher wages with respect to their private forprofit and nonprofit counterparts. Among private organisations, wage differences are overall statistically not significant, although private forprofit organisations and the lay nonprofit organisations (NPO2) pay on average higher wages than religious nonprofit organisations and social cooperatives (NPO1). 
Explaining these wage differentials across organisations is the main aim of the rest of this paper. This section looks at differences in productivity characteristics, especially human capital, and the way they are remunerated across organisations. The main finding is that a sizeable conditional wage gap persists also after controlling for all observable workers’ characteristics.

A specific hypothesis of the next section is that wage differentials across organisations might depend on the hiring and job search methods adopted. As noted in the previous sections, recruitment methods are a tool for employers to assess the productivity level of their workers going beyond the information content of the usual signals, such as education attainment and grades. Differences in recruitment methods across organisations could therefore explain also wage differentials across organisations.

\subsection{Differences in human capital endowment across organisations}

This subsection focuses on differences in characteristics of workers across organisations. If workers in NPOs were significantly less skilled than average, this would already explain wage differences across organisations.

However, this does not seem to be the case. As shown in Table 3, workers in NPOs and in state organisations have slightly more years of education than average. Those employed in NPOs have 12 and NPO2s, in particular, have 12.9 years of education on average, corresponding to upper secondary education attainment. Almost the same applies to state organisations (11.5 years). Workers in FPOs have on average less years of education (10.8). Therefore, differences in educational levels are not stark and tend to be in favour of NPOs.

In addition, workers in state organisations have a significantly higher level of work experience (21.1 years) than workers in FPOs (19.8) and in NPOs (18.2). In NPO2s the average level of work experience is 19.1 years. Job tenure of workers in NPOs (6.7 years) and FPOs (6.8) is lower than that in state organisations (9.6). However, the years of job tenure in NPO2s (8.7) is close to that in the state sector. Overall, the longer work experience of workers in governmental organisations 
might partly explain the state/nonprofit pay gap, but not the nonprofit gap with profit-seeking organisations.

Women prevail on men in any organisational type, representing $75.6 \%$ of the sample. The tendency of women to cluster in the provision of personal services is observed almost universally. The share of women is much higher in FPOs (88.2\%) and state (83.4\%) organisations as compared to NPOs (69\%). Now, considering that generally women have a lower reservation wage and tend hence to accept lower wages than men, then, the prevalence of women in FPOs as opposed to NPOs would suggest that also differences in the gender composition of the workforce cannot explain wage differentials.

Furthermore, governmental organisations are on average much older (88 years) than NPO1s (20.3) and FPOs (13.4). The average age of NPO2s is only 25.7, but this is not a representative value, since the group includes old religious charities (44.8) and recently established social cooperatives $(10.1)^{16}$.

Finally, NPOs tend to concentrate in Northern regions, where the cost of living and the general level of per capita GDP is higher. Also differences in location cannot explain the nonprofit/forprofit wage gap.

\section{[Table 3 about here]}

The enquiry of this subsection has shown that wage differences across organisations cannot be explained only in terms of productivity differences of workers. The level of human capital, as measured in terms of education and of generic and job specific work experience, of workers belonging to nonprofit organisations is not lower than that of their colleagues employed in the profitseeking sector. Only the governmental sector seems to employ more experienced and tenured workers than the private sector. In addition, NPOs employ higher shares of part-time and temporary workers than their forprofit and governmental counterparts.

\subsection{Returns to education}

\footnotetext{
16 The reason why FPOs are younger is that they have been allowed to operate in the supply of social services only recently.
} 
Table 4 reports the results of augmented earnings functions by organisation type. The dependent variable is the log of net hourly wages. Overall, the Adj- $R^{2}$ is higher in FPOs and in the government sector, suggesting that there is a lower degree of occupational heterogeneity in the former types of organisation.

The most apparent finding of Table 4 is that the returns to education are low in the entire social service sector, independent of the type of organisation. Mosca, Musella and Pastore (2007, Table 7) estimated a private annual rate of return to education of about 0.029 in basic earnings equations and of 0.020 when adding all the control variables contained in Table 4. These figures are lower than the low rate of return to education found for the entire country in previous studies (6.6 for men and 7.7 for women, according to Brunello et al., 2000). Forprofit organisations pay a slightly higher than average annual premium to education (0.04) in basic earnings equations, but lower than average annual premium (0.015) in augmented equations. In the sector of nursing and rehabilitation, where the annual rate of return to education is higher than average, profit-seeking firms are more common than state and nonprofit organisations.

The wage effect of holding a university degree or a higher degree amounts only to about $24 \%$, which means an annual rate of return to university education of $2.6 \%$. The private annual rate of return to university education is higher in FPOs and in state organisations, but the rate of return to other post compulsory education degrees is higher in NPOs. The annual rate of return to a year of university education equals 3.2\% for workers in public organisations and 3.7\% for workers in forprofit organisations.

The return to work experience and job tenure is very low in the sector. The returns to work experience and job tenure are higher in NPOs.

\section{[Table 4 about here]}

After controlling for individual and environmental characteristics of workers within the sector, the conditional wage gap across organisations significantly reduces, but is still statistically significant. The state/forprofit gap shrinks from 0.096 (unconditional) to 0.048 (conditional), about a half ${ }^{17}$. The state/NPO1 gap

\footnotetext{
${ }^{17}$ Considering the low coefficients, the Halvorsen and Palmquist (1980) correction of coefficients of dummy variables will be ignored. In fact, in this case, the values are roughly the same.
} 
shrinks from 0.145 to 0.120 , about $20 \%$. The state/NPO2 gap increases from 0.034 to 0.083 . This last result would suggest that NPO2s have higher productivity characteristics than workers in the government sector, but these characteristics are paid less.

Omitted results of an Oaxaca and Ransom (1994) type of decomposition analysis suggest that the explained component of the wage gap between nonprofit organisations and their state and profit-seeking counterparts is around $40 \%$. The rest is due to differences in the way different organisations remunerate their workers.

\section{Results on recruitment channels}

This section focuses on the wage impact of recruitment channels to assess whether differences across organisations can explain wage differentials. Are recruitment channels different across organisations? Which recruitment methods would nonprofit organisations prefer and why? Do some organisations use better recruitment methods than others? Or, rather, different recruitment methods allow access to different types of information on candidates? And finally, are differences in recruitment methods able to determine differences in wages across organisations? Answering these questions is the aim of this section.

\subsection{Descriptive analysis}

Table 5 reports the distribution of workers by hiring methods and organisation types in the social service sector. On average, state organisations use more frequently public competitions for recruiting their employees: $46.1 \%$ of their employees have been hired through public competitions (Caption 1 of Table 5). In principle, this should come as little surprise, since every job in the public sector should be assigned through public competitions according to the Italian Constitution. Nonetheless, the state sector still hires a large number of employees 
without public competitions, some of whom on a temporary basis ${ }^{18}$. FPOs use no public competition at all, whereas a minority share of workers in NPOs has been hired through public competitions. The share is slightly higher in NPO2s (5.0\%) than in NPO1s (2.1\%).

The State, FPOs and NPO1s tend to implement some form of selection for about a quarter of their personnel, but NPO2s for only 19.4\% (caption 2 of Table 5). Consequently, only about a third of workers in the state sector are hired with no selection at all. This share goes up to slightly more than $70 \%$ in other types of organisations (caption 3 of Table 5).

Overall, hiring methods are an important difference among organisation types. The state sector is the most selective in recruiting its personnel. Beyond legal constraints, two possible further explanations of why private organisations prefer to recruit their personnel through informal, rather than formal hiring methods are in order. First, according to a malevolent interpretation, private organisations use informal methods to satisfy the request of the political lobbies on which their financial support depend: in other words, they would hire less skilled protégés to obtain the financial or political support. Based on the theoretical considerations brought to the fore in Section 2, public competitions and other formal selection methods should be a better device to detect personal characteristics and abilities beyond what signalled by the attained level of education. Consequently, these findings could be interpreted as justifying the higher level of monetary remuneration paid by state organisations. In fact, there seems to be a close correlation between the degree of selectivity of hiring methods and the average unconditional wage level by organisation: recall from the previous section that state organisations pay higher wages than NPO2s and FPOs and these last pay higher wages than NPO1s. In other words, people recruited through public competitions might receive higher wages because they were selected in a more accurate way. In the meantime, formal hiring methods are more costly for employers to carry out and for workers to pass through: only workers

\footnotetext{
${ }^{18}$ In fact, as well-known, from time to time, the government issues amnesties to give permanent employment to temporary or project workers who have been working in the public sector for some years. The most recent of such amnesties was issued in 2007 for about 50,000 people in different branches of the public administration.
} 
motivated by the greater monetary compensation of governmental organisations would pay the cost of undergoing a difficult and risky selection process.

Another interpretation, more favourable to private organisations, suggests that informal methods allow a better assessment of the degree of motivation in candidates, holding constant their level of human capital and skill. Forprofit organisations seek workers particularly endowed with work ethic and that they trust. Nonprofit organisations seek workers that share the aims, working methods and mission of the organisation. In other words, different recruitment methods are used to obtain different sets of information and, therefore, in principle, none of them is better than the other. As a matter of fact, in support to this last interpretation, the previous section has shown that the human capital level of personnel in the nonprofits is not lower than that in state and in forprofit organisations.

\section{[Table 5 about here]}

Table 6 shows that informal networks of family and friends are the most common job search method used in the social service sector ${ }^{19}$. Informal networks are more common among workers of NPOs (respectively 33.3\% for NPO1s and $27.3 \%$ for NPO2s) and FPOs (29.1\%) than those in the state sector (12.8\%).

When looking at differences across organisations, it appears that also job search methods markedly differ across organisations, whereas workers employed in the state sector prefer formal (advertisement on newspapers, employment agency and so on) to informal search methods (previous experience as employee, trainee, volunteer or on duty for the civil service within the organisation; previous knowledge of the organisation as a partner, customer or co-resident; and family and friends recommendation). The opposite happens among private organisations.

\section{[Table 6 about here]}

To sum up, the evidence available on the distribution of hiring and job search methods suggests that nonprofit organizations use less frequently formal recruitment methods to obtain information on job candidates. Then the question

\footnotetext{
19 Even if data are difficult to compare, due to the different number of options given to respondents, the share of workers using informal networks as their preferred job search methods in the social service sector is lower than average in Italy. Using SHIW data, Pistaferri (1999) finds a share of about 47\% in 1991 and 38\% in 1993. Using the ECHP, Pellizzari (2004) finds an average share of individuals in the sample using informal networks of 25.5\% for Italy in 1996.
} 
arises of why this is the case. The first possible answer is that state organizations tend to select their personnel better than NPOs and also profit-seeking organizations. The alternative answer is that informal recruitment methods allow for a better selection of workers who are interested more in non-pecuniary than in pecuniary compensations. In turn, if this is the case, it might also be possible that in nonprofit organizations informal networks bring with them a wage premium, rather than a wage penalty. This hypothesis would be also consistent with the view that informal networks are more effective as a selection device when formal recruitment channels are less common.

\subsection{Econometric estimates}

This section aims to assess the impact of hiring and job search methods on wages and, therefore, on the wage gap across organisations. Table 7 reports results of Mincerian earnings equations augmented with controls for hiring methods (but not for job search methods). Workers hired through a public competition are in the baseline. In the entire sample, being hired through public competitions brings with it a wage premium of about $10 \%$ as compared to hiring without selection, of just less than $7 \%$ as compared to hiring with some form of selection and about $20 \%$ for those who do not answer the relevant question. In addition, the returns to education slightly reduce in all sectors.

The impact of public competitions is different across organisations. The greatest impact is not in the state sector, but in NPO2s, where it yields a wage premium of about $16 \%$ as compared to those undergoing no selection and about

$9 \%$ to those undergoing some form of selection. Those not declaring their hiring method experience a wage penalty of over $30 \%$ of their wages. The impact of hiring methods is statistically insignificant in FPOs and NPO1s.

\section{[Table 7 about here]}

Third, interestingly enough, once controlling for hiring methods, wage differentials across organisations are strongly reduced or turn to statistical insignificance. The coefficient of the dummy for the private sector is not significant anymore. This suggests that the positive wage gap between state and 
FPOs is entirely explained by hiring methods. Also the coefficient of the dummy for NPO2s shrinks by a half with respect to that obtained in augmented earnings equations and reduces its significance level. The coefficient for NPO1s shrinks by about $30 \%$ (from -0.120 to -0.079 ), but remains statistically significant. The reduction is of about 55\% with respect to the unconditional gap. The reduction in the conditional wage gap across organisations once controlling for hiring channels would suggest that state organisations using public competition procedures select employees with a good quality, if not quantity of education, which was excluded in previous sections. Table 8 summarises the coefficients of organisations' dummies in different specifications of the earnings function.

\section{[Table 8 about here]}

Table 9 reports the results of earnings equations augmented with both hiring and job search methods. The first important result is that the wage effect of hiring methods is reduced by the introduction of controls for job search methods, whereas the coefficients of organisations' dummies remain substantially unchanged (columns (3) and (4) of Table 8). In other words, job search methods catch part of the impact of hiring methods, but not that on wage differentials across organisations. There is apparently some relationship between hiring and job search methods: state organisations use more formal hiring methods and, hence, also more formal job search methods (answering advertisements on newspapers and so on). Consequently, the wage effect of being hired through a public competition reduces now from $10 \%$ to $7 \%$ for those hired with no selection, from $6.8 \%$ to $4.5 \%$ for those hired with some form of selection and from $20 \%$ to $18 \%$ for those missing to declare their entry channel.

Interestingly, family and friends bring with them a statistically significant and negative wage effect $(-6.5 \%)$ in the state sector where public competitions are common, whereas they yield a statistically significant and positive wage effect (6.3\%) in social cooperatives and religious nonprofit organisations. This would confirm the hypothesis, already formulated above, that job search methods have a different function and therefore yield different impact on wages in different organisation types. In the governmental sector, where formal methods are considered necessary to assess the productivity level in candidates, being hired 
through informal networks is seen as a sign of low productivity. Conversely, in nonprofit organisations, informal networks are seen as the best way to assess not only the productivity level, but also the degree of ideological motivation and, hence, yield a positive wage effect.

Other job search methods are also able to affect wages. Having had a previous professional collaboration with the organisations generates a wage premium of about $10 \%$ in all sectors. This result is especially due to workers employed in nonprofit organisations, where the wage premium of previous professional collaborations raises to about $15 \%$. This result is stable across different specifications and confirms the importance of direct knowledge of workers in the sector in general and in NPOs in particular.

Having served for the civil service, instead causes a wage penalty of about $15 \%$ in the entire sector. The impact is due to those employed in nonprofit organisations. The positive and statistically significant coefficient for having answered advertisements on newspaper is probably related to people winning a public competition. In fact, the coefficient of this variable becomes higher in the estimates without hiring methods (Table 10). Having previously been a customer in social cooperatives causes a wage premium. This is in the nature itself of social cooperatives of Type $B$, which have the obligation to hire some of their customers, namely disadvantaged people.

\section{[Table 9 about here]}

Table 10 presents the same estimates as in Table 9, but without controls for hiring methods. The significance level of variables remains unchanged, but the wage effect of job search methods, especially those related to public competitions (especially job vacancy published on newspapers), is slightly increased.

\section{[Table 10 about here]}

Table 11 replicates previous estimates providing the coefficient of informal networks only with and without controls for hiring methods. This is done for comparative purposes, since previous research has used this variable, without controls for other job search methods. The coefficient is statistically significant only for state organisations, in which case it is negative, like in previous estimates. Having been hired through informal networks yields a wage penalty of 
$5 \%$ if one controls for hiring methods and $8 \%$ without controls for hiring methods. These coefficients are similar to those in previous estimates. However, different from other estimates, the coefficient is not statistically significant for NPO1s. This finding is a warning against the use of informal networks without controls for other job search methods. The set of answers available in the questionnaire might drive the results when estimating the wage effect of referrals.

\section{[Table 11 about here]}

Are informal networks an exogenous determinant of wages? Or are they a signal of workers' ability? Previous studies find much evidence that low skill workers use informal networks more frequently. Informal networks are also common in markets for very high skill workers. This might suggest that informal networks are just a signal of above/below average unobserved skills in candidates. In other words, the wage effect associated with informal networks would not be due to informal networks themselves, but rather to the skill level of those who use this job search method. IV estimates might be used to test for endogeneity of informal networks. However, the data do not provide suitable instruments to implement IV estimation procedures and, hence, we adopt an indirect approach to the issue based on the following line of reasoning. If informal networks are not just a signal of skills, but, rather, an independent factor causing a wage penalty/premium, this wage premium/penalty should disappear with time. In fact, as soon as workers understand that their wages are lower/higher than they should be based on their skills, then, in case of a wage penalty, workers will leave the firm in search for higher wages and, in case of a wage premium, firms will understand the real skill level of workers and adjust wages to it. Vice versa, if informal networks were just a signal of skills, then, the wage penalty/premium associated with it should continue over time: in this case, in fact, workers would have no reason to move to seek wage improvements, in case of wage penalty, and firms would have no reason to reduce wages, in case of wage premium. To test these alternative hypotheses, we check whether the coefficients in equation (4) are statistically different from each other. Table 12 reports the coefficients of the dummies for informal networks interacted with tenure and the results of the test of equality of coefficients. 
The differences in coefficients are sizeable in the two cases in which informal networks are statistically significant, namely in the estimates relative to governmental organisations and NPO1s. The difference in coefficients is about $50 \%$ or more. Results of the test of equality of coefficients suggest rejecting the null hypothesis in one case only, namely for basic earnings equations relative to governmental organisations. However, the F-statistics is close to significance also in other cases, except for the augmented earnings equations relative to NPO1s. More degree of freedoms would probably turn these test statistics to significance. Overall, the tests seem to reject the hypothesis of endogeneity of informal networks.

Two years of job tenure are a reasonable assumption in the social service sector in Italy, where the unemployment rate is high and the labour legislation particularly binding for firms. A different period of time (e.g. Pellizzari, 2004, considers 6 months) would be either too short or too long. However, unreported sensitivity analysis with different job tenures does not seem to change the results. Simply the differences in coefficients slightly flatten. This is reassuring of the fact that the reduction is related to the exact time necessary for workers and firms to adjust, rather than being the consequence of the threshold chosen.

\section{[Table 12 about here]}

Unreported estimates implement the same type of test for public competitions interacted with years of job tenure. Recall from the beginning of this section that public competitions are used almost exclusively in the state sector and in NPO2s. The results of such tests allow rejecting the null hypothesis of equality of coefficients in the case of governmental organisations, but not in the case of NPO2s. This might suggest that public competitions yield a specific wage premium only in the former case.

\section{Discussion}

The econometric analysis of the previous sections has led to the following results: a) wages are higher in the state sector than in profit-seeking and NPO2s and even higher than in NPO1s, the type of organisations that are closest to the 
nonprofit mission, namely social cooperatives and religious institutions; b) state owned organisations use formal methods of hiring (especially public competitions) more frequently than FPOs and NPO1s and even more frequently than NPO2s; c) also job search methods tend to differ across organisations: workers employed in the state sector have used formal (advertisement on newspapers, employment agency and so on) rather than informal methods (previous experience as employee, trainee, volunteer or on duty for the civil service within the organisation; previous knowledge of the organisation as a partner, a customer or co-resident; and family and friends recommendations); the opposite applies to workers in private organisations; d) unconditional wage differentials across organisations disappear or strongly reduce after controlling for hiring and job search methods; e) public competitions bring with them a sizeable wage premium; f) informal networks yield a wage premium in NPO1s and a wage penalty in state organisations, while they are statistically insignificant in FPOs and NPO2s.

In principle, these findings can be interpreted in two alternative ways. First, following the previous literature on the wage impact of hiring and job search methods (see, among others, Montgomery, 1991; Ioannides and Datcher Loury, 2004), one can interpret the previous findings as evidence in favour of the hypothesis that the higher is the degree of formality of recruitment methods adopted, the higher is also the ability of these methods to solve the ex ante asymmetric information problem that employers have to face when recruiting their employees. This would explain the higher wage level attached to jobs accessed through formal recruitment methods. In turn, this conclusion would bring support to the view that nonprofit organisations tend to hire low productivity workers often recurring to informal hiring methods because they tend to favour political and social lobbies. In addition, this would depend on the need of NPOs to seek political support to carry out their activities. Nonetheless, NPOs would bear the cost of their inefficient recruitment methods in terms of a lower productivity level of their personnel and, hence, of the quality of the services provided. Like in Goldberg's (1982) model, nonprofit institutions would still survive because they maximise utility, rather than profit. 
The alternative explanation is that the degree of formality of hiring and job search methods is not so important in terms of the quantity of the information achieved, but of its quality. More specifically, while both formal and informal methods would equally allow knowing the productivity level of workers (level and quality of human capital, which, in fact, are signalled also by academic titles and credentials and can therefore be known also through informal methods), informal methods would also allow knowing the degree of motivation in candidates, their work ethic, sharing aims and mission of the organisation and so on. In addition to the legal obligation to hire through public competitions, stated in the Italian constitution, the need to assess the degree of motivation of workers hired in public organisations would be less important than in forprofit and even more in nonprofit organisations.

The reason why private organisations prefer informal methods of hiring are different from those of the nonprofit sector. In the case of private forprofit organisations, their small size itself requires knowing the sense of work ethic and trust in candidates. This right is also recognised in the Italian law (art. 8, law 604 of 1966) whereas firms with 15 employees or less can fire their workers even not for cause, which is forbidden to bigger firms. In the case of nonprofit organisations, instead, knowing the tendency of workers to share the organisation's mission would be more important. Informal methods would better suit the needs to select ideologically motivated personnel in NPOs, especially NPO1s. Previous research has argued that nonprofit organisations would tend to hire ideologically motivated workers by paying them less: low monetary remuneration would cause a self-selection mechanism (Handy and Katz, 1998; Mosca, Musella and Pastore, 2007). This paper adds to the previous literature by suggesting that in addition to lower than average monetary compensations, informal recruitment methods are part of the process of self-selection of motivated workers in nonprofit organisations. According to this interpretation, the disappearance of the conditional wage gap across organisations would be not the consequence of better hiring and job search methods in state organisations, but of different hiring strategies of nonprofit as compared to state and forprofit organisations. 
There is no econometric test able to choose one of these two alternative interpretations of the same findings, as also Devaro (2005) notes. However, theoretical reasoning based on the evidence provided in this paper as well as in the previous literature would suggest that the latter interpretation of our findings is to be preferred. In fact, if public concourses were a better hiring method, as supposed in the first interpretation, then workers employed in state organisations should hold a higher level of human capital and supply their services more efficiently. However, this seems not to be the case in the data considered. In fact, section 4 of this paper has provided clear evidence that human capital differences are not in favour of state organisations. In addition, using the same dataset, Mosca, Musella and Pastore (2007) find that the degree of motivation and job satisfaction is much higher in workers employed in the nonprofit than in the state sector, despite wage differences in favour of the latter. Furthermore, using the organisations' file of the same data, Destefanis and Maietta (2003) show that there are no statistically significant efficiency differences between public and nonprofit organisations. However, when the degree of motivation of employees is controlled for, efficiency differences become statistically significant in favour of the state sector. They interpret this finding as evidence that the lower degree of motivation of workers in state organisations causes efficiency losses. In turn, overall, this would suggest that informal recruitment methods are equally able to detect the human capital level in job candidates. Therefore, the use of different recruitment methods should depend on other reasons but choosing the best candidate, at least if measured in terms of human capital endowment.

Second, if informal are less effective than formal methods, as suggested in the first interpretation, the wage effect of informal methods should be negative not only in the state sector, but also in nonprofit organisations. However, it is positive in social cooperatives and religious nonprofit organisations. This finding might suggest a further explanation of Pellizzari's (2004) hypothesis that informal networks are less efficient when formal hiring methods are more common: firms might prefer informal recruitment methods when they aim to assess not only the level and quality of human capital, but also the degree of motivation in potential candidates, as noted before. 
Third, while, in principle, public competitions should be more accurate than informal hiring methods, nonetheless, there is large anecdotal evidence that public concourses are fixed in Italy ${ }^{20}$. The choice of one hiring method rather than another might therefore be driven not so much by the need to select the best candidate, but each hiring method would be more effective in obtaining a specific set of information on characteristics in candidates.

\section{Conclusions}

According to a malevolent interpretation, the recent excellent performance of the Italian tertiary sector would have happened in an era of hard budget constraint for the state. The nonprofits would have substituted the good jobs typical of the government sector with jobs of low quality. They would prefer informal recruitment methods because these methods would serve the scope of hiring low skill protégés of political lobbies to obtain financial support.

This paper addresses these criticisms in two ways. First, it looks at the quality of employment and at the returns to education across organisation types operating in the social service sector. Workers in nonprofit organisations have the same, if not a higher level of human capital than their colleagues in the service sector. Moreover, the common view that nonprofit organisations pay low returns to human capital is due more to a sector, rather than to an organisation specific feature. Returns to human capital are typically low in the low productivity social service sector, independent of the organisation type. University (but not other types of high) education obtains a slightly greater payoff in profit-seeking than in public and nonprofit organisations, though this might be some form of compensation for the lower returns to generic and job specific work experience in the former type of organisations. In addition, other returns to post-compulsory education are higher in NPOs.

Second, the paper aims to test whether differences in the choice of recruitment channels across organisation types may partly explain the negative nonprofit wage gap of social cooperatives and religious nonprofit against profit-

\footnotetext{
${ }^{20}$ A recent journalistic book (Rizzo and Stella, 2007) provides plenty of anecdotal evidence of the corruption of public competitions and of the pervasive role of political parties in fixing the results of concourses in any branch of the state sector in Italy.
} 
seeking and, even more, governmental organisations within the sector. We find that, independent of the organisations' type, being hired through public competitions brings with it a substantial wage premium (ranging from 7 to 32\% according to the organisation). Informal networks bring with them a wage penalty $(-6.5 \%)$ in the state sector, where formal hiring methods are common, and a wage premium (6.3\%) in NPO1s, where formal hiring methods are not common. Employees with previous relationship of professional collaboration with the organisation, employees recruited through job vacancies published on specialised newspapers obtain a wage premium. Conversely, employees with a previous experience of civil service in the organisation discount a wage penalty.

Interestingly, the differences in hiring and in job search methods between state and private organisations explain from $50 \%$ to $100 \%$ of conditional wage differentials across organisation types. A possible interpretation of this finding is that state organisations using public competitions to select their employees are actually able to choose the most skilled candidates and this justifies the higher monetary remunerations they pay. An alternative explanation is that organisations in the governmental sector prefer formal recruitment methods because of the legal constraints, whereas private organisations prefer informal recruitment methods to obtain information not only on skill levels, which are in fact similar across organisations, but also on other individual characteristics, such as work ethic and trust in the case of profit-seeking firms and sharing the aims, values and mission of the organisation in the case of nonprofit institutions. Informal hiring and job search methods are a complement to lower than average wages to form an organisation specific recruitment method aimed at selecting the most ideologically motivated personnel.

Econometric tests to control for endogeneity of hiring and job search methods suggest that they are actually able to solve the asymmetric information problem between employers and employees, rather than being a signal of the skill level in candidates.

From a policy perspective, the paper suggests that different recruitment methods are necessary to reduce the ex ante information asymmetries existing between employers and employees across different types of organisations. In 
particular, formal hiring and job search methods need not necessarily to be the best instrument to select the most skilled among otherwise identical individuals, as the previous wisdom would suggest. When ideological motivation is an important quality in candidates, informal recruitment methods might be more efficient. 


\section{References}

Addison, J. T and P. Portugal, (2002), “Job search methods and outcomes”, Oxford Economic Papers, 54(3): 505-533.

Akerlof, G. A. and J. L. Yellen, (1990), “The Fair Wage-Effort Hypothesis and Unemployment”, The Quarterly Journal of Economics, 105(2), 255-283.

Akerlof, G. A., (1984), “Gift exchange and efficiency wage theory: four views”, American Economic Review, 74(2), 79-83.

Antoninis M., (2006), "The wage effects from the use of personal contacts as hiring channels”, Journal of Economic Behavior \& Organization, 59(1): 133-146.

Bentolila S., C. Michelacci and J. Suàrez (2004), "Social Contacts and Occupational Choice”, CEPR discussion paper, N. 4308.

Blau, D. M. and R. Philip K, (1990), "Job Search Outcomes for the Employed and Unemployed”, Journal of Political Economy, 98(3): 637-55.

Brunello, G, S. Comi and C. Lucifora (2000), “The Returns to Education in Italy: a New Look at the Evidence”, IZA discussion paper, N. 130, March.

Bull C., O. Ornati and P. Tedeschi (1987), "Search, Hiring Strategies, and Labor Market Intermediaries”, Journal of Labor Economics, 5(4): S1-S17.

Cahuc P. and F. Fontaine (2002), "On the Efficiency of Job-Search with Social Networks”, CEPR Discussion Paper n. 3511.

Calvò-Armengol, A. (2004), “Job Contact Networks”, Journal of Economic Theory, 115(1): 191-206.

Calvò-Armengol, A. and M.O. Jackson (2004), "The Effect of Social Networks on Employment and Inequality”, American Economic Review, 94(3): 426-454.

Calvò-Armengol A., Zenou Y. (2001), "Job Matching, Social Networks and Word-of-Mouth Communication”, CEPR Discussion Paper Series n. 2797.

Card, D., (1999) “The Casual Effect of Education on Earnings”, in Aschenfelter, O. C. and D. Card, (eds), Handbook of Labor Economics, North-Holland: Amsterdam, III A: 1801-1863.

Carinci, F.(2001), "Questioni giuslavoristiche in tema di organizzazioni di volontariato e di cooperative sociali”, Italian Labour Law E-Journal, vol. III, n. 3.

Collier, P. and A. Garg (1999), "On Kin Groups and Wages in the Ghanaian Labour Market”, Oxford Bulletin Of Economics and Statistics, 61(2): 133151.

Corcoran, M., L. Datcher Loury and G.J. Duncan (1980), "Most Workers Find Jobs through Word of Mouth”, Monthly Labour Review, 103(8): 33-35. 
Datcher Loury, L., (2006), "Some Contacts Are More Equal than Others: Informal Networks, Job Tenure, and Wages”, Journal of Labor Economics, 24 (2): 299-318.

Datcher Loury, L., (2006), “Job search among informal contacts”, Department of Economics Tufts University, Discussion paper, N. 604.

Delattre, E and M. Sabatier, (2007), “Social Capital and Wages: An Econometric Evaluation of Social Networking's Effects”, Labour, 21(2): 209-236.

Destefanis, S. and O. Maietta (2003), “La determinazione dell'efficienza produttiva nel settore nonprofit”, in C. Borzaga and M. Musella (eds.), Produttività ed efficienza nelle organizzazioni nonprofit. Il ruolo dei lavoratori e delle relazioni di lavoro, Edizioni 31, Trento.

Devaro, J. (2005), "Employer Recruitment Strategies and the Labour Market Outcomes of New Hires”, Economic Enquiry, 43(2): 263-282.

Frank, R. H., (1996), "What Price the Moral High Ground?”, Southern Economic Journal, 63(): 1-17.

Goddeeris, J. H., (1988), "Compensating Differentials and Self-Selection: An Application to Lawyers”, Journal of Political Economy, 96(2): 411-428.

Goldberg, M., (1982) "Discrimination, nepotism, and long-run wage differentials", Quarterly Journal of Economics, 97(2): 307-319.

Goos M. and A. Salomons (2007), "Dangerous Liaisons: A Social Network Model for the Gender Wage Gap”, Catholic University of Leuven, mimeo.

Gregg, P. and J. Wadsworth (1996), "How Effective Are State Employment Agencies? Jobcentre Use and Job Matching in Britain”, Oxford Bulletin of Economics and Statistics, 58(3): 443-67.

Halvorsen, R. and R. Palmquist (1980), “The Interpretation of Dummy Variables in. Semilogarithmic Equations”, American Economic Review, 70(3): 474475.

Handy, F. and E. Katz, (1998), "The wage Differential between Nonprofit Institution and Corporations: Getting More by Paying Less?”, Journal of Comparative Economics, 26 (2): 246-261.

Hansmann, H., (1980), “The Role of Nonprofit enterprise”, Yale Law Journal, 89(5): 835-901.

Holzer, H. J, (1987), “Job Search by Employed and Unemployed Youth”, Industrial and Labor Relations Review, 40(4): 601-611.

Holzer, H. J. (1988) "Search Method Use by Unemployed Youth," Journal of Labor Economics, 6(1): 1-20.

Ioannides, Y. M. and L. Datcher Loury, (2004), "Job Information Networks, Neighborhood Effects, and Inequality”, Journal of Economic Literature, 42(4): 1056-1093.

Kugler, A.D. (2003), “Employee referrals and efficiency wages”, Labour Economics, 10(5): 531-556. 
Lazear, E. P., (1991), "Labour Economics and the Psychology of Organizations”, Journal of Economic Perspectives, 5(2): 89-110.

Leete, L., (2000), "Wage Equity and Employment Motivation in Nonprofit and Forprofit Organisations", Journal of Economic Behaviour and Organisation, 43(4): 423-446.

Leete, L., (2001), "Whither the Nonprofit Wage Differential? Estimates from the 1990 Census”, Journal of Labour Economics, 19(1): 136-170.

Margolis, D. N. and V. Simonnet (2003), "Educational Track, Networks and Labor Market Outcomes”, Iza discuson paper, No. 699

Marmaros, D. and Sacerdote B (2002), "Peer andsocial networks in job search", European Ecomic Review 46, 870 - 879.

Meliciani, V and D. Radicchia (2005), "Returns of Educations in Italy: The role of labour market recruitment channels”, mimeo.

Menchik, P. L. and B. A. Weisbrod, (1987), "Volunteer Labor Supply”, Journal of Public Economics, 32 (2): 159-183.

Mendolicchio D., (2006), “A Disaggregate Analysis of Private Returns to Education in Italy”, UCL Discussion Paper 2006-54.

Montgomery, J. (1991), "Social Networks and Labor Market Outcomes", American Economic Review, 81(5): 1408-1418.

Mortensen D., Vishwanath T. (1994), "Personal Contacts and Earnings. It is who you know!”, Labour Economics, 1(2): 187-201.

Mosca, M., M. Musella and F. Pastore (2007), "Relational Goods, Monitoring and Non-Pecuniary Compensations in the Nonprofit Sector: The Case of the Italian Social Services", Annals of Public and Cooperative Economics, 78(1): 55-86.

Oaxaca, R and Ransom, M. (1994), "On Discrimination and the Decomposition of Wage Differentials”, Journal of econometrics, 61(1): 5-21.

Osberg L., (1993), "Fishing in Different Pools: Job-Search Strategies and JobFinding Success in Canada in the Early 1980s." Journal of Labor Economics, 11(02): 348-386.

Pastore, F. (2008), “School-to-Work Transition in Mongolia”, Employment Policy Papers 2008/1, Geneva: International Labour Office.

Pellizzari, M. (2004), “Do Friends and Relatives Really Help in Getting a Good Job?, Centre for Economic Performance, Discussion paper, N. 623, March.

Pestana Barros, C. (2006), "Earnings, Schooling and Social Capital of Cooperative Managers", Annals of Public and Cooperative Economics, 77(1): 1-20.

Pistaferri L. (1999), “Informal Networks in the Italian Labor Market”, Giornale degli Economisti e Annali di Economia, 58(3-4): 355-375.

Preston, A. E., (1989), “The Nonprofit Worker in a Forprofit World”, Journal of Labor Economics, 7(4): 438-463. 
Psacharopoulos, G. (1994). Returns to Investment in Education: a Global Update. World Development, 22(9): 1325-1343.

Rees, A. (1966), “Information Networks in Labor Markets”, American Economics Review, 56(1/2): 559-566.

Rizzo, S. and G. Stella (2007), La casta. Così i politici italiani sono diventati intoccabili, Rizzoli, Milano.

Roper S. (1988), “Recruitment Methods and Vacancy Duration”, Scottish Journal of Political Economy, 35(1): 51-64.

Rose-Ackerman, S. (1996), “Altruism, Nonprofits and Economic Theory”, Journal of Economic Literature, 34(2): 701-728.

Ruhm, C. and C. Borkoski, (2000), “Compensation in the Nonprofit Sector”, NBER working paper, N. 7562.

Saloner G. (1985), “Old Boy Networks as Screening Mechanisms”, Journal of Labor Economics, 3(3): 255-267.

Simon, Curtis, and John Warner (1992), "Matchmaker, Matchmaker: The Effect of Old Boy Networks on Job Match Quality, Earnings, and Tenure”, Journal of Labor Ecomics, 10(3): 306-30.

Sylos Labini, M. (2004), "Social Networks and Wages: It is All About Connections!”, W.P. LEM, n. 10, Sant’Anna School of Advanced Studies.

Sylos Labini, M. (2005), "Job Search Methods and Outcomes for the Employed and Unemployed: an empirical investigation”, W.P. LEM, Sant'Anna School of Advanced Studies.

Thomas, J. (1997), "Public employment agencies and unemployment spells: Reconciling the experimental and nonexperimental evidence”, Industrial and Labor Relations Review, 50(4): 667-683.

Weber, A. and H. Maringher (2007), "Choice and Success of Job Search Methods", Empirical Economics, 


\section{Appendix of Tables and Figures}

Table 1. Survey of previous findings on hiring and job search methods

\begin{tabular}{|c|c|c|c|c|c|}
\hline & \multicolumn{5}{|c|}{ Impact on the probability of job finding } \\
\hline Authors & Data bank & $\begin{array}{l}\text { Country and } \\
\text { years }\end{array}$ & $\begin{array}{l}\text { Estimation } \\
\text { method (OLS, } \\
\text { IV etc) }\end{array}$ & $\begin{array}{l}\text { If control } \\
\text { for hiring } \\
\text { methods }\end{array}$ & Impact on the probability of job finding and on wages \\
\hline Holzer (1987b) & $\begin{array}{l}\text { New Youth Cohort of the National } \\
\text { Longitudinal Survey (NLS) }\end{array}$ & USA: 1981 & Probit & Yes & $\begin{array}{l}\text { Different search choices partly explain differences in search outcomes of } \\
\text { unemployed searchers and employed and searchers. The former record higher } \\
\text { rate of job acceptance but with lower wages. }\end{array}$ \\
\hline Holzer (1988) & $(N L S)$ & USA: 1979 & Probit & No & $\begin{array}{l}\text { Search method choices related to their costs and expected productivities. are } \\
\text { also the most productive in generating job offers and acceptances. }\end{array}$ \\
\hline Roper (1988) & $\begin{array}{l}\text { Survey of employers' recruitment } \\
\text { practices }\end{array}$ & USA: $1976-` 77$ & Probit & No & $\begin{array}{l}\text { Informal search is also the most productive channel for firms (in terms of } \\
\text { expected duration). }\end{array}$ \\
\hline $\begin{array}{l}\text { Blau and } \\
\text { Robins (1990) }\end{array}$ & $\begin{array}{l}\text { Employment Opportunity Pilot } \\
\text { Projects (EOPP) }\end{array}$ & USA: 1980 & OLS, probit & No & $\begin{array}{l}\text { Job seekers using informal contacts have higher probability of finding a job } \\
\text { than unemployed job seekers }\end{array}$ \\
\hline Osberg (1993) & $\begin{array}{l}\text { Longitudinal data from } \\
\text { Labour Force Survey (LFS). }\end{array}$ & $\begin{array}{l}\text { Canada: } \\
1981,1983 \text {, and } \\
1986\end{array}$ & Logit and probit & No & $\begin{array}{l}\text { Job-search methods change with the business cycle and many people find jobs } \\
\text { without any reported search }\end{array}$ \\
\hline $\begin{array}{l}\text { Lindeboom et } \\
\text { al. (1994) }\end{array}$ & $\begin{array}{l}\text { Manpower Survey } \\
\text { 'Arbeidskrachtentelling' } \\
\text { (AKT) and the Vacancy Survey of } \\
\text { the Netherlands Central Bureau of } \\
\text { Statistics (CBS), two panel surveys } \\
\text { conducted by the Organization for } \\
\text { Labour Market Research (OSA). }\end{array}$ & $\begin{array}{l}\text { The } \\
\text { Netherlands } \\
\text { 1985-1987 }\end{array}$ & Probit & No & Large differences in the effectiveness of the search channels. \\
\hline \multirow[t]{2}{*}{$\begin{array}{l}\text { Sylos } \\
(2005)\end{array}$} & SHIW & Italy: 1993 & Bivariate probit & Yes & $\begin{array}{l}\text { Public employment agencies for the unemployed and checking with friends for } \\
\text { the employed are the most widespread search methods. On-the-job seekers } \\
\text { use less methods (a proxy of search effort), but descriptive evidence shows } \\
\text { that they generate more offers and have higher job finding rates for most of } \\
\text { the method condered. Once we control for endogeneity of method choice and } \\
\text { for personal characteris. }\end{array}$ \\
\hline & \multicolumn{5}{|c|}{ Wage effects } \\
\hline Authors & Data bank & $\begin{array}{l}\text { Country and } \\
\text { years }\end{array}$ & $\begin{array}{l}\text { Estimation } \\
\text { method (OLS, }\end{array}$ & $\begin{array}{l}\text { If control } \\
\text { for hiring }\end{array}$ & Impact on the probability of job finding and on wages \\
\hline
\end{tabular}




\begin{tabular}{|c|c|c|c|c|c|}
\hline & & & IV etc) & methods & \\
\hline $\begin{array}{l}\text { Simon and } \\
\text { Warner (1992) }\end{array}$ & $\begin{array}{l}\text { Survey on Natural and Social } \\
\text { Scientists and Engineers }\end{array}$ & USA: 1972 & OLS & No & $\begin{array}{l}\text { Workers hired through the old boy networks earn higher initial salaries (from } \\
0.034 \text { to 0.087), experience lower wage growth on the job and stay on the job } \\
\text { longer than otherwise comparable workers hired from outside the network. }\end{array}$ \\
\hline $\begin{array}{l}\text { Pistaferri } \\
\text { (1999) }\end{array}$ & $\begin{array}{l}\text { Bank of Italy Survey of Household } \\
\text { Income and Wealth (SHIW) }\end{array}$ & $\begin{array}{l}\text { Italy: } 1991 \text { and } \\
1993\end{array}$ & $\begin{array}{l}\text { OLS, annual } \\
\text { earnings; IV } \\
\text { (Instruments are: } \\
\text { father education } \\
\text { and occupation). }\end{array}$ & No & $\begin{array}{l}\text { Negative and statistically significant coefficient: }-0.046 \text {. When controlling for } \\
\text { low wage sectors and occupations: }-0.031 \text {. OLS underestimates wage effects, } \\
\text { which become: }-0.071 \text { and controlling for firm size }-0.039 \text {. }\end{array}$ \\
\hline $\begin{array}{l}\text { Collier and } \\
\text { Garg (1999) }\end{array}$ & Living Standards Survey & Ghana: 1989 & $\begin{array}{l}\text { OLS with } \\
\text { Heckman-Lee } \\
\text { corrections }\end{array}$ & No & Wage premium for kinship equals $25 \%$. \\
\hline $\begin{array}{l}\text { Marmaros and } \\
\text { Sacerdote } \\
\text { (2002) }\end{array}$ & $\begin{array}{l}\text { Survey of Dartmouth College } \\
\text { Seniors }\end{array}$ & USA: 2001 & OLS & No & $\begin{array}{l}\text { Informal networks significantly affect the probability to access high paying } \\
\text { jobs }\end{array}$ \\
\hline Kugler (2003) & $\begin{array}{l}\text { National Longitudinal Survey of } \\
\text { Youths (NLSY) and Current } \\
\text { Population Survey(CPS) }\end{array}$ & $\begin{array}{lr}\text { USA: } & 1982 \\
(N L S Y) & \text { and } \\
1984(C P S) & \end{array}$ & $\begin{array}{l}\text { OLS, } \\
\text { wages }\end{array}$ & NO & $\begin{array}{l}\text { Positive statistically significant wage effect: } 0.04 \text {. Controlling for tenure: } \\
0.01 \text {. }\end{array}$ \\
\hline $\begin{array}{l}\text { Margolis and } \\
\text { Simonnet (2003) }\end{array}$ & Youth and Career Survey by INSEE & France: 1997 & $O L S$ & Yes & $\begin{array}{l}\text { Individuals who found their } 1997 \text { job via informal contacts earn significantly } \\
\text { more than those who found their job by any other method (16\% more than } \\
\text { market methods, } 34 \% \text { more than intermediaries and } 13 \% \text { more than other } \\
\text { methods). }\end{array}$ \\
\hline $\begin{array}{l}\text { Pellizzari } \\
\text { (2004) }\end{array}$ & $\begin{array}{l}\text { Europeans Community Household } \\
\text { Panel (ECHP) and National } \\
\text { Longitudinal Survey of Youths } \\
\text { (NLSY) }\end{array}$ & $\begin{array}{l}\text { Europe: } 1994- \\
1999 ; \quad \text { USA: } \\
1979-1999\end{array}$ & OLS & No & Large cross-country and cross-industry variation in the wage differentials \\
\hline $\begin{array}{l}\text { Bentoilila, } \\
\text { Michelacci and } \\
\text { Suarez (2004) }\end{array}$ & $\begin{array}{l}\text { Multi-city Study of Urban } \\
\text { Inequality (MCSUI) and ECHP }\end{array}$ & $\begin{array}{l}\text { USA: 1992-'94; } \\
\text { EU: } 1994-{ }^{-9} 98\end{array}$ & $\begin{array}{l}\text { OLS, hourly } \\
\text { wages }\end{array}$ & No & $\begin{array}{l}\text { Social contacts reduce the time to wait by } 1-2 \text { months, but lead to individual } \\
\text { wage discounts of } 5 \% \text { to } 7 \% \text {. }\end{array}$ \\
\hline $\begin{array}{l}\text { Sylos } \quad \text { Labini } \\
(2004)\end{array}$ & $\begin{array}{l}\text { Survey on university to job } \\
\text { transition, ISTAT }\end{array}$ & Italy: 1998 & $\begin{array}{l}\text { OLS, hourly } \\
\text { wages }\end{array}$ & Yes & $\begin{array}{l}\text { Negative wage effect for all informal networks }(-0.025) \text {. Networks of family } \\
\text { and friends yield a wage penalty (-0.047), whereas networks of colleagues } \\
\text { yield a wage premium (0.025). }\end{array}$ \\
\hline $\begin{array}{l}\text { Meliciani and } \\
\text { Radicchia } \\
\text { (2005) }\end{array}$ & $\begin{array}{l}\text { Data provided by ISFOL (Institute } \\
\text { for the Development of the } \\
\text { Vocational Training of Workers) } \\
\text { and collected in }\end{array}$ & Italy: 2003 & $\begin{array}{l}\text { OLS, Probit and } \\
\text { IV (sample of } \\
\text { sons) }\end{array}$ & Yes & $\begin{array}{l}\text { Informal contacts generates a wage penalty of }-0.037 \text { with respect to public } \\
\text { competitions, direct applications, direct experience on the job and schools }\end{array}$ \\
\hline $\begin{array}{l}\text { Antoninis } \\
\text { (2006) }\end{array}$ & $\begin{array}{l}\text { Personnel files of a manufacturing } \\
\text { firm }\end{array}$ & Egypt: 2000 & OLS & No & $\begin{array}{l}\text { No wage effect in general. When controlling for source of referrals, he finds } \\
\text { for skilled jobs no statistically significant negative effect }(-0.055) \text { for families }\end{array}$ \\
\hline
\end{tabular}




\begin{tabular}{|c|c|c|c|c|c|}
\hline $\begin{array}{l}\text { Datcher Loury } \\
\text { (2006) }\end{array}$ & $N L S Y$ & USA: 1982-‘03 & $\begin{array}{l}\text { OLS, annual } \\
\text { earnings }\end{array}$ & No & $\begin{array}{l}\text { and friends and significant positive effect for old colleagues (0.347); for } \\
\text { unskilled jobs a significant wage penalty for family and friends (-0.140) and } \\
\text { no statistically significant wage premium }(0.114) \text {. } \\
\text { Negative wage premium for men relying on female contacts }(-0.066) \text {; positive } \\
\text { wage premium for men relying on male contacts }(0.151) \text {; positive wage } \\
\text { premium for women relying on male contacts }(0.129) \text {; not significant effect } \\
\text { for women relying on female contacts. }\end{array}$ \\
\hline $\begin{array}{l}\text { Delattre and } \\
\text { Sabatier (2007) }\end{array}$ & $\begin{array}{l}\text { French Longitudinal Survey: } \\
\text { 'Trajectoires des Demandeurs } \\
\text { d'Emploi et Marchés Locaux } \\
\text { du Travail' (TDE-MLT) by DARES }\end{array}$ & France: 1995 & $\begin{array}{l}\text { OLS, IV and } \\
\text { switching } \\
\text { regression } \\
\text { model,, hourly } \\
\text { wages }\end{array}$ & No & $\begin{array}{l}\text { No statistical significant wage effect (OLS and IV); informal networks yield a } \\
\text { statistically significant wage penalty of } 7 \% \text { in the case of Switching regression } \\
\text { models. }\end{array}$ \\
\hline $\begin{array}{l}\text { Goos and } \\
\text { Salomons } \\
\text { (2007) }\end{array}$ & $\begin{array}{l}\text { Quarterly Labour Force Survey } \\
\text { (LFS) }\end{array}$ & UK: 2001-'06 & $\begin{array}{ll}\text { OLS, } & \text { hourly } \\
\text { wages } & \end{array}$ & Yes & $\begin{array}{l}\text { Men (0.053) receive higher average referral wage premium than women } \\
(0.015) \text {. Referral wage premium for men and women increases with years of } \\
\text { education. Networks explain a significant part of the gender wage gap for } \\
\text { newly hired workers. }\end{array}$ \\
\hline $\begin{array}{l}\text { Weber and } \\
\text { Mahringer } \\
\text { (2007) }\end{array}$ & $\begin{array}{l}\text { Ad hoc survey of successful job } \\
\text { seekers }\end{array}$ & Styria (Austria) & $\begin{array}{l}\text { OLS and IV, } \\
\text { annual earnings }\end{array}$ & No & $\begin{array}{l}\text { OLS estimates yield no statistically significant effect of informal networks. IV } \\
\text { estimates yield a } 0.18 \text { wage penalty, but it is not statistically significant. } \\
\text { Instruments used: are career attitude, city indicator, dummy whether the } \\
\text { successful channel was also used as search method, dummies for job loss } \\
\text { following firm closure or layoff. }\end{array}$ \\
\hline Pastore (2008) & School-to-Work Survey & Mongolia: 2006 & OLS & No & $\begin{array}{l}\text { For the entire sample: }-0.1134 \text {. It is statistically significant only for young } \\
\text { people aged } 25-29(-0.1706) \text { and for men }(-0.199)\end{array}$ \\
\hline
\end{tabular}


Table 2. Average monthly and hourly wages by organisation type

All workers (monthly wages)

\begin{tabular}{lcccccc}
\hline & State & FPOs & NPOs & $\begin{array}{c}\text { Social } \\
\text { cooperati } \\
\text { ves } \\
\text { (NPO2) }\end{array}$ & $\begin{array}{c}\text { Lay } \\
\text { organisati } \\
\text { ons } \\
\text { (NPO1) }\end{array}$ & $\begin{array}{c}\text { Religious organisations } \\
\text { (NPO2) }\end{array}$ \\
\hline State & & & & & & \\
FPOs & 9.6 & & & & \\
NPOs & 16.2 & 6.0 & & & \\
Social cooperatives (NPO2) & 22.7 & 12.0 & 5.6 & & \\
Lay organisations (NPO1) & 7.0 & -2.3 & -7.8 & -12.8 & \\
Religious organisations (NPO2) & 17.8 & 7.5 & 1.4 & -4.0 & 10.0 & \\
\hline
\end{tabular}

Full-time workers (monthly wages)

\begin{tabular}{|c|c|c|c|c|c|c|}
\hline & State & FPOs & NPOs & $\begin{array}{l}\text { Social } \\
\text { cooperati } \\
\text { ves } \\
(\mathrm{NPO})\end{array}$ & $\begin{array}{l}\text { Lay } \\
\text { organisati } \\
\text { ons } \\
\text { (NPO1) }\end{array}$ & $\begin{array}{l}\text { Religious organisations } \\
\text { (NPO2) }\end{array}$ \\
\hline \multicolumn{7}{|l|}{ State } \\
\hline FPOs & 12.4 & & & & & \\
\hline NPOs & 13.1 & 0.6 & & & & \\
\hline Social cooperatives (NPO2) & 16.8 & 3.9 & 3.3 & & & \\
\hline Lay organisations (NPO1) & 5.5 & -6.2 & -6.7 & -9.7 & & \\
\hline Religious organisations (NPO2) & 18.2 & 5.2 & 4.5 & 1.2 & 12.1 & \\
\hline \multicolumn{7}{|c|}{ Part-time workers (hourly wages) } \\
\hline & State & FPOs & NPOs & $\begin{array}{l}\text { Social } \\
\text { cooperati } \\
\text { ves } \\
(\mathrm{NPO})\end{array}$ & $\begin{array}{l}\text { Lay } \\
\text { organisati } \\
\text { ons } \\
\text { (NPO1) }\end{array}$ & $\begin{array}{l}\text { Religious organisations } \\
\text { (NPO2) }\end{array}$ \\
\hline \multicolumn{7}{|l|}{ State } \\
\hline FPOs & -12.2 & & & & & \\
\hline NPOs & 2.3 & 16.6 & & & & \\
\hline Social cooperatives (NPO2) & 10.5 & 25.9 & 8.0 & & & \\
\hline Lay organisations (NPO1) & -9.6 & 3.0 & -11.6 & -18.2 & & \\
\hline Religious organisations (NPO2) & 4.1 & 18.6 & 1.7 & -5.8 & 15.2 & \\
\hline
\end{tabular}

Note: Each figure in the table shows the ratio between column (j) and row (i): $w_{j} / w_{i}$. Therefore a positive sign indicates a premium in favour of the organisation type showed in the column.

Recall also that we include in NPO2 social cooperatives and religious organisations.

Source: own elaboration on ISSAN data. 
Table 3. Workers characteristics by sector and organisation type

\begin{tabular}{|c|c|c|c|c|c|}
\hline \multirow[t]{2}{*}{ Variables } & \multicolumn{5}{|c|}{ Organisations } \\
\hline & Governmental & Forprofit & Nonprofit & NPO1 & NPO2 \\
\hline Age (years) & 38.6 & 36.5 & 36.2 & 35.3 & 38.0 \\
\hline Education (years): & 11.5 & 10.8 & 12.0 & 11.6 & 12.9 \\
\hline No title (\%) & 0.2 & / & / & 0.5 & I \\
\hline Primary school (\%) & 4.2 & 12.0 & 4.8 & 5.3 & 3.8 \\
\hline Low secondary school (\%) & 18.6 & 27.4 & 21.1 & 24.7 & 13.9 \\
\hline Vocational secondary school (\%) & 32.3 & 20.0 & 13.7 & 15.0 & 10.9 \\
\hline High secondary school (\%) & 34.0 & 26.9 & 40.5 & 38.5 & 44.7 \\
\hline University degree (\%) & 4.0 & 9.7 & 8.7 & 7.5 & 11.4 \\
\hline Postgraduate (\%) & 6.7 & 4.0 & 10.7 & 8.4 & 15.4 \\
\hline Work experience (years) & 21.1 & 19.8 & 18.2 & 17.7 & 19.1 \\
\hline Tenure (years) & 9.6 & 6.8 & 6.7 & 5.8 & 8.7 \\
\hline Age of organisation (years) & 88.0 & 13.4 & 22.1 & 20.3 & 25.7 \\
\hline Women $(\%)$ & 84.4 & 88.0 & 72.1 & 73.9 & 68.4 \\
\hline \multicolumn{6}{|l|}{ Civil status: } \\
\hline Single (\%) & 24.6 & 32.0 & 36.1 & 37.3 & 33.8 \\
\hline Married (\%) & 65.4 & 53.7 & 58.6 & 54.3 & 56.8 \\
\hline Divorced (\%) & 7.9 & 9.1 & 7.2 & 6.8 & 7.8 \\
\hline Widow (\%) & 2.1 & 5.1 & 1.6 & 1.6 & 1.5 \\
\hline \multicolumn{6}{|l|}{ Macro-regions: } \\
\hline North-West (\%) & 41.8 & 68.6 & 32.5 & 39.3 & 18.7 \\
\hline North-East (\%) & 48.8 & 9.7 & 38.1 & 34.7 & 44.9 \\
\hline Centre (\%) & 1.2 & 5.7 & 7.8 & 7.7 & 8.1 \\
\hline South (\%) & 8.2 & 16.0 & 21.6 & 18.4 & 28.3 \\
\hline Part-time (\%) & 14.0 & 14.3 & 25.3 & 25.6 & 24.8 \\
\hline \multicolumn{6}{|l|}{ Sector: } \\
\hline Assistance and guardianship (\%) & 52.1 & 77.1 & 45.9 & 49.1 & 39.5 \\
\hline Nursing/Rehabilitation (\%) & 8.6 & 21.7 & 7.9 & 5.1 & 13.7 \\
\hline Educational (\%) & 34.2 & / & 22.9 & 27.5 & 13.7 \\
\hline Cultural (\%) & / & / & / & / & 0.8 \\
\hline Recreational (\%) & 4.6 & / & 1.8 & 1.7 & 2.0 \\
\hline School/school-to-work guidance (\%) & 0.5 & / & l & / & 9.9 \\
\hline Job-search assistance (\%) & / & / & 12.2 & 15.9 & 4.8 \\
\hline Other services (\%) & / & 1.1 & 5.7 & 0.7 & 15.7 \\
\hline \multicolumn{6}{|l|}{ Occupation: } \\
\hline Home assistant (\%) & 14.9 & 1.7 & 12.4 & 14.2 & 8.8 \\
\hline Social assistant (\%) & 1.9 & 6.9 & 2.1 & 1.5 & 3.3 \\
\hline Social assistant operator (OSA) (\%) & 17.9 & 22.4 & 12.0 & 13.4 & 9.1 \\
\hline Educator (\%) & 33.6 & 5.2 & 28.8 & 28.0 & 30.3 \\
\hline Generic nurse (\%) & 1.6 & 4.0 & 0.8 & 0.9 & 0.5 \\
\hline Professional nurse (\%) & 4.0 & 9.8 & 3.5 & 4.1 & 2.3 \\
\hline Medical doctor (\%) & 1.6 & / & l & l & l \\
\hline Therapist/Psychologist (\%) & 1.4 & 9.2 & 5.1 & 2.7 & 9.8 \\
\hline Sociologist (\%) & 0.2 & / & 0.2 & 0.1 & 0.3 \\
\hline Other $(\%)$ & 10.9 & 27 & 12.8 & 12.9 & 12.4 \\
\hline
\end{tabular}

Note: NPO1 social cooperatives and religious nonprofits, NPO2 lay nonprofits. Social assistants are without qualification.

Source: Our elaboration. 
Table 4. Augmented Mincerian earnings equations by organisation

\begin{tabular}{|c|c|c|c|c|c|c|}
\hline Variables & All & State & FPO & NPO & NPO1 & NPO2 \\
\hline (Constant) & $8.965^{* * *}$ & $8.980^{* * *}$ & $9.372^{* * *}$ & $8.794^{* * *}$ & $8.851^{* * *}$ & $8.851^{* * *}$ \\
\hline Men & 0.010 & -0.030 & -0.055 & $0.037^{* *}$ & 0.035 & 0.043 \\
\hline University degree and above & $0.237^{* * *}$ & $0.285^{* * *}$ & $0.340^{* * *}$ & $0.234^{* * *}$ & $0.193^{* * *}$ & $0.218^{* * *}$ \\
\hline Bachelor degree & $0.160^{* * *}$ & 0.068 & $0.114^{*}$ & $0.206^{* * *}$ & $0.190^{* * *}$ & $0.175^{* *}$ \\
\hline High secondary school & $0.100^{* * *}$ & $0.075^{* * *}$ & 0.024 & $0.125^{* * *}$ & $0.089^{* * *}$ & $0.148^{* * *}$ \\
\hline Professional qualification & $0.049^{* * *}$ & $0.048^{*}$ & 0.030 & $0.046^{* * *}$ & 0.027 & 0.092 \\
\hline Work Experience & $0.014^{* * *}$ & $0.006^{*}$ & -0.008 & $0.019^{* * *}$ & $0.015^{* * *}$ & $0.019^{* * *}$ \\
\hline Squared work experience & $0.000^{* * *}$ & 0.000 & 0.000 & $0.000^{* * *}$ & $0.000^{* * *}$ & $0.000^{* * *}$ \\
\hline Tenure & $0.003^{* * *}$ & 0.002 & $0.002^{* * *}$ & $0.003^{*}$ & $0.003^{* *}$ & 0.003 \\
\hline North-East & $0.065^{* * *}$ & $0.130^{* * *}$ & $0.287^{*}$ & 0.045 & 0.013 & 0.043 \\
\hline North-West & 0.009 & $0.100^{* *}$ & $0.155^{* *}$ & -0.005 & -0.010 & -0.030 \\
\hline Centre (Florence) & -0.012 & $0.362^{* * *}$ & 0.144 & -0.026 & -0.010 & -0.062 \\
\hline Singles & -0.019 & -0.007 & $-0.077^{* *}$ & -0.015 & -0.020 & -0.035 \\
\hline Divorced/widowed & -0.003 & 0.023 & 0.037 & -0.011 & 0.012 & -0.056 \\
\hline Part-time workers & $0.099^{* * *}$ & $0.080^{* * *}$ & $0.167^{* * *}$ & $0.110^{* * *}$ & $0.117^{* * *}$ & $0.127^{* * *}$ \\
\hline Coordinator & 0.028 & 0.076 & -0.066 & 0.017 & 0.049 & -0.021 \\
\hline Assistance and guardianship & $-0.039^{* * *}$ & -0.032 & $-0.373^{* * *}$ & $-0.038^{* *}$ & -0.011 & $-0.090^{* * *}$ \\
\hline Home and social care & -0.016 & $-0.054^{*}$ & $-0.107^{* *}$ & 0.005 & 0.011 & -0.006 \\
\hline Generic/ professional nurse & $0.146^{* * *}$ & $0.111^{* * *}$ & 0.067 & $0.180^{* * *}$ & $0.208^{* * *}$ & 0.092 \\
\hline Social assistance operator & -0.030 & $-0.073^{* * *}$ & $-0.079^{* *}$ & 0.002 & 0.021 & -0.034 \\
\hline Teacher /Educator & 0.014 & $0.081^{* * *}$ & $0.191^{* * *}$ & -0.020 & -0.040 & 0.031 \\
\hline Therapist & $0.209^{* * *}$ & $0.300^{* * *}$ & 0.027 & $0.193^{* * *}$ & $0.338^{* * *}$ & 0.085 \\
\hline Work and training contracts & $-0.198^{* * *}$ & $-0.420^{* * *}$ & -0.136 & 0.016 & 0.063 & 0.055 \\
\hline Temporary worker & $0.051^{* *}$ & 0.015 & 0.055 & $0.057^{*}$ & $0.082^{* *}$ & 0.040 \\
\hline Occasional worker & $0.139^{* * *}$ & -0.005 & 0.109 & $0.149^{* * *}$ & $0.116^{* * *}$ & $0.141^{* *}$ \\
\hline Union contract & $0.047^{* * *}$ & $0.077^{* * *}$ & 0.041 & $0.033^{*}$ & 0.012 & 0.055 \\
\hline Often going on strike & 0.037 & 0.037 & 0.087 & -0.023 & -0.056 & 0.050 \\
\hline FPS & $-0.048^{* *}$ & & & & & \\
\hline NPS1 & $-0.120^{* * *}$ & $-0.120^{* * *}$ & & & & \\
\hline NPS2 & $-0.083^{* * *}$ & & & & & \\
\hline Adj-R ${ }^{2}$ & 0.24 & 0.37 & 0.58 & 0.20 & 0.18 & 0.22 \\
\hline Number of observations & 1946 & 570 & 175 & 1201 & 805 & 396 \\
\hline
\end{tabular}

Note: *. **. ${ }^{* * *}$ denote significance levels of 10.15 and 1 per cent respectively.

The Huber/White/sandwich estimator of variance is used to correct for heteroskedasticity.

The natural log of hourly wages is the dependent variable. The benchmark variables are married women with low secondary education or below, working with in a full-time permanent contract job in state organisations located in Southern regions, operating in any service but assistance and guardianship, and without a specific type of occupation, not going always on strike.

FPO stands for forprofit organisations; NPO1 for social cooperatives and religious nonprofits; NPO2 for other lay nonprofits.

Source: Own elaboration on ISSAN data 
Table 5 Hiring methods (in \%)

\begin{tabular}{llllll}
\hline 1. Public competition & State & FPO & NPO1 & NPO2 & Total \\
\hline No & 53.9 & 100.0 & 97.9 & 95.0 & 84.6 \\
Yes & 46.1 & 0.0 & 2.1 & 5.0 & 15.4 \\
Total & 100.0 & 100.0 & 100.0 & 100.0 & 100.0 \\
& & & & & \\
\hline 2. Direct assumption with & State & FPO & NPO1 & NPO2 & Total \\
selection among more candidates & & & & & \\
\hline No & & & & & \\
Yes & 77.5 & 73.1 & 76.7 & 80.6 & 77.4 \\
Total & 22.5 & 26.9 & 23.3 & 19.4 & 22.6 \\
& 100.0 & 100.0 & 100.0 & 100.0 & 100.0 \\
\hline 3. Direct assumption without selection & State & FPO & NPO1 & NPO2 & Total \\
\hline No & 68.4 & 28.6 & 26.1 & 26.5 & 38.8 \\
Yes & 31.6 & 71.4 & 73.9 & 73.5 & 61.2 \\
Total & 100.0 & 100.0 & 100.0 & 100.0 & 100.0 \\
N. obs. & 570 & 175 & 805 & 396 & 1946 \\
& & & & & \\
\hline
\end{tabular}

Source: Own elaboration on ISSAN data.

Table 6. Job search methods (in \%)

\begin{tabular}{|c|c|c|c|c|c|}
\hline Contact & State & FPO & NPO1 & NPO2 & Total \\
\hline $\begin{array}{l}\text { Previous relationship of professional collaboration with the } \\
\text { organization }\end{array}$ & 6.0 & 9.7 & 9.3 & 15.4 & 9.6 \\
\hline $\begin{array}{l}\text { Affiliation to an association or group (religious or not) to } \\
\text { which the organization is connected }\end{array}$ & 1.6 & 1.7 & 5.3 & 5.6 & 4.0 \\
\hline Civil service in the organization & 0.2 & 0.0 & 1.9 & 1.8 & 1.2 \\
\hline $\begin{array}{l}\text { Customer (or customer' relatives) of the services disbursed by } \\
\text { the organization }\end{array}$ & 1.9 & 4.0 & 3.0 & 6.6 & 3.5 \\
\hline Signalling of relatives and friends & 12.8 & 29.1 & 33.3 & 27.3 & 25.7 \\
\hline $\begin{array}{l}\text { I have known the organization because it operates in the } \\
\text { territorial area in which I live }\end{array}$ & 9.5 & 21.1 & 17.9 & 13.9 & 14.9 \\
\hline Experience of voluntary job in the organization & 2.8 & 0.6 & 8.2 & 6.6 & 5.6 \\
\hline $\begin{array}{l}\text { Job vacancies published on the specialised newspapers or } \\
\text { publication of public competition }\end{array}$ & 39.3 & 8.0 & 2.5 & 3.0 & 13.9 \\
\hline Employment office (or similar structure) & 12.3 & 12.6 & 2.2 & 2.3 & 6.1 \\
\hline Other & 13.7 & 13.1 & 16.4 & 17.7 & 15.6 \\
\hline Total & 100.0 & 100.0 & 100.0 & 100.0 & 100.0 \\
\hline N. obs. & 570 & 175 & 805 & 396 & 1946 \\
\hline
\end{tabular}


Table 7. Mincerian equations augmented with hiring methods

\begin{tabular}{l|ccccc}
\hline Variable & All & State & FPO & NPO1 & NPO2 \\
\hline Men & 0.0147 & -0.0281 & -0.0502 & 0.0370 & 0.0514 \\
Laurea & $0.2224^{* * *}$ & $0.2630^{* * *}$ & $0.3347^{*}$ & $0.1929^{* * *}$ & $0.2074^{* * *}$ \\
Bachelor degree & $0.1481^{* * *}$ & 0.0395 & 0.1106 & $0.1878^{* * *}$ & $0.1704^{* * *}$ \\
General Secondary & $0.0931^{* * *}$ & $0.0573^{*}$ & 0.0202 & $0.0882^{* *}$ & $0.1463^{* * *}$ \\
Vocational Secondary & $0.0444^{* *}$ & 0.0318 & 0.0197 & 0.0264 & 0.0961 \\
Pot. work exp. & $0.0132^{* * *}$ & 0.0048 & -0.0077 & $0.0151^{* * *}$ & $0.0185^{* * *}$ \\
Pot. work exp. $\wedge 2$ & $-0.0002^{* * *}$ & -0.0001 & 0.0001 & $-0.0003^{* *}$ & $-0.0003^{* * *}$ \\
Job tenure & $0.0028^{* *}$ & $0.0026^{*}$ & 0.0026 & $0.0029^{*}$ & 0.0038 \\
FPO & -0.0051 & & & & \\
NPO1 & $-0.0787^{* * *}$ & & & & \\
NPO2 & $-0.0410^{*}$ & & & & \\
Hiring with no selection & $-0.1009^{* * *}$ & $-0.0867^{* * *}$ & & -0.0284 & $-0.1623^{* * *}$ \\
Hiring with selection & $-0.0680^{* * *}$ & -0.0189 & 0.0587 & -0.0322 & $-0.0886^{*}$ \\
Hiring missing & $-0.2042^{* *}$ & 0.0270 & & -0.1243 & $-0.3212^{* *}$ \\
Constant & $9.0309^{* * *}$ & $9.0421^{* * *}$ & $9.3411^{* * *}$ & $8.8826^{* * *}$ & $9.0017^{* * *}$ \\
Number of observations & 1.946 & 570 & 175 & 805 & 396 \\
$\mathrm{R}^{2}$ & 0.26 & 0.42 & 0.67 & 0.20 & 0.29 \\
\hline
\end{tabular}

Note: See the Notes under Table 2. The coefficients of civil status, regional, industry, occupation and union membership are omitted. In addition, the benchmark group is further restricted to those individuals who have been hired through a public competition. No employee in the FPOs has been hired through a public competition and only very few do not answer to the question on the hiring method adopted. In this case, the baseline is "hiring with no selection or missing observation on hiring".

Source: Own elaboration on ISSAN data

Table 8. Wage differentials across organisations after controlling for recruitment methods

\begin{tabular}{l|ccccc}
\hline & $(1)$ & $(2)$ & $(3)$ & $(4)$ & $(5)$ \\
\hline FPOs & $-0.095^{* * *}$ & $-0.048^{* *}$ & -0.005 & -0.007 & -0.027 \\
NPO1 & $-0.145^{* * *}$ & $-0.120^{* * *}$ & $-0.079^{* * *}$ & $-0.077^{* * *}$ & $-0.093^{* * *}$ \\
NPO2 & $-0.034^{*}$ & $-0.083^{* * *}$ & $-0.041^{*}$ & $-0.043^{*}$ & $-0.060^{* *}$ \\
\hline
\end{tabular}

Note: (1) Unconditional regression; (2) Augmented earning equation (see Table 4); (3) Augmented earning equation with hiring methods (Table 7); (4) Augmented earning equation with hiring and job search methods (Table 9); (5) Augmented earning equation with job search methods only (Table 10). Source: own elaboration on ISSAN data. 
Table 9. Mincerian equations augmented with hiring and job search methods

\begin{tabular}{|c|c|c|c|c|c|}
\hline Variable & All & State & FPO & NPO1 & NPO2 \\
\hline Men & 0.0217 & -0.0305 & -0.0427 & 0.0451 & 0.0583 \\
\hline Laurea & $0.2119 * * *$ & $0.2601 * * *$ & $0.3523^{* *}$ & $0.1869 * *$ & $0.1935 * * *$ \\
\hline Bachelor degree & $0.1381^{* * *}$ & 0.0563 & 0.1165 & $0.1825 * * *$ & $0.1511 * *$ \\
\hline General Secondary & $0.0917 * * *$ & $0.0590 *$ & 0.0150 & $0.0841^{* *}$ & $0.1463 * * *$ \\
\hline Vocational Secondary & $0.0437 * *$ & 0.0362 & 0.0100 & 0.0183 & $0.0956 *$ \\
\hline Pot. work exp. & $0.0123 * * *$ & 0.0046 & -0.0068 & $0.0143^{* * *}$ & $0.0165 * * *$ \\
\hline Pot. work exp. $\wedge 2$ & $-0.0002 * * *$ & -0.0001 & 0.0001 & $-0.0003 * *$ & $-0.0003^{* * *}$ \\
\hline Job tenure & $0.0028 * *$ & $0.0029 *$ & 0.0023 & 0.0024 & 0.0043 \\
\hline Hiring with no selection & $-0.0711 * * *$ & $-0.0789 * *$ & & -0.0363 & $-0.1377 * *$ \\
\hline Hiring with selection & $-0.0445^{*}$ & -0.0098 & 0.0398 & -0.0429 & -0.0630 \\
\hline Hiring missing & $-0.1779 *$ & 0.0248 & & -0.1000 & $-0.3241 * *$ \\
\hline FPO & -0.0073 & & & & \\
\hline NPO1 & $-0.0772 * * *$ & & & & \\
\hline NPO2 & $-0.0431 *$ & & & & \\
\hline Previous professional collaboration & $0.0984 * * *$ & 0.0089 & -0.0813 & $0.1561 * * *$ & $0.1486 * * *$ \\
\hline Affiliation to an association & 0.0173 & 0.0085 & -0.0714 & 0.0550 & 0.0738 \\
\hline Civil service in the organisation & $-0.1494 *$ & & & -0.1312 & -0.0386 \\
\hline Customer & 0.0426 & 0.0586 & -0.1196 & $0.1468 * *$ & 0.0181 \\
\hline Relatives and friends & 0.0139 & $-0.0652 *$ & -0.0178 & $0.0632 *$ & 0.0166 \\
\hline Co-resident of the organisation & 0.0105 & -0.0104 & -0.0488 & 0.0266 & 0.0468 \\
\hline Previously Volunteer & -0.0272 & -0.0418 & & 0.0375 & -0.0124 \\
\hline Job vacancies published on newspapers & $0.0602 * *$ & -0.0099 & 0.0533 & 0.0627 & $0.0922 *$ \\
\hline Employment office & -0.0097 & -0.0274 & -0.0009 & -0.0452 & 0.0301 \\
\hline Constant & $8.9925 * * *$ & $9.0622 * * *$ & $9.3729 * * *$ & $8.8474 * * *$ & $8.9524 * * *$ \\
\hline $\mathrm{N}$ & 1.946 & 570 & 175 & 805 & 396 \\
\hline $\mathrm{R}^{2}$ & 0.28 & 0.43 & 0.68 & 0.23 & 0.32 \\
\hline
\end{tabular}

Note: See the Notes under Table 7. In addition, the benchmark group is further restricted to those individuals who have been hired through a public competition and have used "other job search methods". No employee in the FPOs has been hired through a public competition and only very few do not answer to the question on the hiring method adopted. In this case, the baseline is "hiring with no selection or missing observation on hiring".

Source: own elaboration on ISSAN data. 
Table 10. Mincerian equations augmented with job search methods

\begin{tabular}{l|lllll}
\hline Variable & All & State & FPO & NPO1 & NPO2 \\
\hline Men & 0.0192 & -0.0324 & -0.0428 & 0.0433 & 0.0489 \\
Laurea & $0.2205^{* * *}$ & $0.2769^{* * *}$ & $0.3522^{* *}$ & $0.1881^{* * *}$ & $0.2004^{* * *}$ \\
Bachelor degree & $0.1432^{* * *}$ & 0.0719 & 0.1143 & $0.1843^{* * *}$ & $0.1524^{* *}$ \\
General Secondary & $0.0951^{* * *}$ & $0.0721^{*}$ & 0.0177 & $0.0846^{* *}$ & $0.1441^{* * *}$ \\
Vocational Secondary & $0.0446^{* *}$ & 0.0469 & 0.0156 & 0.0191 & 0.0874 \\
Pot. work exp. & $0.0126^{* * *}$ & 0.0056 & -0.0072 & $0.0145^{* * *}$ & $0.0177^{* * *}$ \\
Pot. work exp. $\wedge 2$ & $-0.0002^{* * *}$ & -0.0001 & 0.0001 & $-0.0003^{* *}$ & $-0.0004^{* * *}$ \\
Job tenure & $0.0027^{* *}$ & $0.0026^{*}$ & 0.0020 & $0.0025^{*}$ & 0.0038 \\
FPO & -0.0274 & & & & \\
NPO1 & $-0.0932^{* * *}$ & & & & \\
NPO2 & $-0.0600^{* *}$ & & & & \\
Previous professional collaboration & $0.0994^{* * *}$ & 0.0202 & -0.0850 & $0.1573^{* * *}$ & $0.1388^{* *}$ \\
Affiliation to an association & 0.0157 & 0.0211 & -0.1044 & 0.0541 & 0.0675 \\
Civil service in the organisation & $-0.1481^{*}$ & & & -0.1269 & -0.0111 \\
Customer & 0.0390 & 0.0379 & -0.1222 & $0.1487^{* *}$ & 0.0214 \\
Relatives and friends & 0.0143 & $-0.0760^{*}$ & -0.0169 & $0.0643^{*}$ & 0.0139 \\
Co-resident of the organisation & 0.0131 & -0.0106 & -0.0493 & 0.0273 & 0.0545 \\
Previously Volunteer & -0.0313 & -0.0508 & & 0.0400 & -0.0302 \\
Job vacancies published on newspapers & $0.0981^{* * *}$ & 0.0232 & 0.0687 & $0.0808^{*}$ & $0.1836^{* * *}$ \\
Employment office & -0.0087 & -0.0140 & -0.0021 & -0.0443 & 0.0097 \\
Constant & $8.9354^{* * *}$ & $8.9950^{* * *}$ & $9.3936 * * *$ & $8.8070^{* * *}$ & $8.8246^{* * *}$ \\
N & 1,946 & 570 & 175 & 805 & 396 \\
$\mathrm{R}^{2}$ & 0.27 & 0.42 & 0.66 & 0.23 & 0.30 \\
\hline
\end{tabular}

Note: See the Notes under Table 2. The coefficients of civil status, regional, industry, occupation and union membership are omitted. In addition, the benchmark group is restricted to those individuals who have used other job search methods but those in the table.

Source: Own elaboration on ISSAN data

Table 11. The role of networks only

\begin{tabular}{l|lcccc}
\hline Variables & ALL & STATE & FPO & NPO1 & NPO2 \\
\hline & \multicolumn{5}{c}{ Controlling for hiring methods } \\
\hline Relatives and friends & -0.0041 & $-0.0567^{*}$ & 0.0085 & 0.0219 & -0.0312 \\
\hline & \multicolumn{5}{c}{ No controls for hiring methods } \\
\hline Relatives and friends & 0.0106 & $-0.0808^{* *}$ & 0.0094 & 0.0217 & 0.0371 \\
\hline
\end{tabular}

Note: The estimates include all the control variables included in Table 9 and 10, respectively.

Source: Own elaboration on ISSAN data

Table 12. Informal networks and tenure profile

\begin{tabular}{l|rrrrr}
\hline Variables & \multicolumn{1}{|l}{ ALL } & STATE & FPO & NPO1 & NPO2 \\
\hline & \multicolumn{5}{|c}{ In basic earnings equations } \\
\hline Family and friends*2 years of tenure & 0.0429 & $-0.2897^{* *}$ & 0.0886 & $0.1485^{*}$ & -0.0503 \\
Family and friends*more years of tenure & -0.0025 & $-0.0939^{*}$ & -0.0576 & $0.0637^{*}$ & -0.0271 \\
\hline Wald-test of $\mathrm{H}_{0}: \beta_{1}-\beta_{2}=0$ & 1.14 & \multicolumn{7}{c}{$3.95^{* *}$} & 2.27 & 2.05 & 0.10 \\
\hline & \multicolumn{7}{c}{ In augmented earnings equations } \\
\hline Family and friends*2 years of tenure & 0.0238 & $-0.1655^{*}$ & 0.0591 & 0.0922 & -0.0034 \\
Family and friends*more years of tenure & 0.0110 & -0.0506 & -0.0388 & 0.0532 & 0.0211 \\
\hline Wald-test of $\mathrm{H}_{0}: \beta_{1}-\beta_{2}=0$ & 0.11 & 2.62 & 0.85 & 0.53 & 0.13 \\
\hline
\end{tabular}

Note: Basic earnings equations include only human capital variables, whereas augmented earnings equations include all the variables as in Table 9.

Source: Own elaboration on ISSAN data 